\title{
Üç-altı yaş çocuklarına yönelik öykülerin sosyal beceriler açısından incelenmesi
}

\author{
An examinations of stories for children aged three to six \\ in terms of social skills
}

\begin{abstract}
Pinar Aksoy ${ }^{1}$
Makale Geçmişi

Geliş : : 7 Ağustos 2019

Düzeltme : 17 Nisan 2020

Kabul : 3 Temmuz 2020

\section{Makale Türü}

Arasstrma Makalesi

Öz: Bu çalıșmada üç-altı yaș çocuklarına yönelik öykülerin sosyal beceriler açısından incelenmesi amaçlanmıştır. Araştırmada durum çalışması deseni kullanılmıştır. Çalışma amaçlı örnekleme yöntemlerinden ölçüt örnekleme yöntemi doğrultusunda ulaşılan farklı yayınevleri tarafindan yayınlanmış okul öncesi dönem çocuklarına yönelik olan öyküler üzerinde yürütülmüştür. Çalışma grubunu, 2009-2019 yılları arasında yayınlanmıș üç-altı yaş çocuklarına yönelik toplamda 60 öykü kitabı oluşturmaktadır. Çalışma verilerinin toplanmasında, doküman incelemesi yöntemine ve elde edilen verilerin analizinde, içerik analizine başvurulmuştur. Çalışma sonucunda, ele alınan öykülerde daha çok olumlu yönde desteklenecek şekilde sosyal becerilerin yer aldığı ve ağırlıklı olarak hatasını kabul etme ile teşekkür etme, akabinde yardım etme ile duygu ve düşüncelerini ifade etme ve beraberinde özür dileme ve birlikte oynama gibi sosyal becerilerin öne çıkarıldığı görülmüştür. Öykülerin \% 13.33’ünde bir şekilde sosyal becerileri olumsuz yönde etkileyebilecek birkaç unsurun yer aldığı da saptanmıştır. Öykülerde işlenen sosyal becerilerin çoğunlukla "iletişim" boyutu ve akabinde "prososyal davranışlar" boyutu altında yer alan sosyal beceriler olduğu görülürken, nadiren de "kendini kontrol" boyutundan sosyal beceriler olduğu saptanmıştır. Okul öncesi dönem çocuklarına yönelik öykülerin bağımsız davranma, kendine güvenme, cesur olma, liderlik gösterme, hakkını savunma, korku/kayg1 verici durumlarla baş etme ve öfkesini kontrol etme gibi sosyal beceriler açısından daha zengin hale getirilmesi ve öykülerin sosyal beceriler açısından sahip olduğu unsurların hedef kitle için öykü seçim kriterleri arasında dikkate alınması gerekmektedir.
\end{abstract}

Article History

Received : 7 August 2019

Revised : 17 April 2020

Accepted : 3 July 2020

Article Type

Research Article
Anahtar Kelimeler: Okul öncesi dönem, çocuk yazını, öykü kitabı, sosyal beceriler.
Abstract: This study was conducted for the purpose of examining of stories for children aged three to six in terms of social skills. In this case study design was used. The study was carried on stories, which were reached in line with the criterion sampling method from the purposive sampling methods, published by different publishing companies for preschool children. The study group consists of 60 storybooks in total, which were published by various publishing companies, for children aged three to six, between the years 2009 and 2019. Document review method was used to collect study data, and content analysis method was adopted to analyze the obtained data. As a result of the study, it was seen that social skills were mostly included in the stories to be supported in a positive way and social skills of accepting his/her mistake and thanking are emphasized in the stories mainly, followed by the social skills such as helping and expressing feelings and thoughts, and besides apologizing and playing together. It was also found that $13.33 \%$ of the stories contained a few elements that could negatively affect social skills in any way. It was seen in the study findings that the social skills included in the stories are mainly in the dimensions of "communication" and then the dimensions of "prosocial behaviors", while it was revealed that the social skills in the dimensions of "self-control" is rare. Stories for preschool children should be enriched in terms of social skills such as acting independently, self-confidence, being brave, showing leadership, defending the right, coping with fearful/worrisome situations and controlling their anger and the factors that stories have in terms of social skills should be taken into consideration among the story selection criteria for target group.

Keywords: Preschool period, child's literature, story book, social skills. 


\section{SUMMARY}

\section{Introduction}

Picture books, offering preschool children, who cannot read and write, a visual feast with vivid colors, pictures, and figures in them, ensure children to be introduced to letters, words, and sentences. Story is a genre of literature in which true or possible events are expressed shortly in the context of time, space and a character. Chain of events, presented to children in a well-fictionalized manner suitable for their nature, not only allows children to describe their own lives and backgrounds, but also gives them the opportunity to gain new experiences basing on the cases of lives fictionalized by the author (Kaya Bağdaş and Demir, 2016; Oruç, 2010; Sever, 2003). Stories contribute to gaining social skills, which consist of verbal and non-verbal behaviors, ensuring children to establish positive social relations with others and to sustain the relations they establish. The more important part is how stories for preschool children approach social skill education and in what direction the manners of stories to structure social skills are. This study was conducted for the purpose of examining of stories for children aged three to six in terms of social skills. For this purpose, answers to the following questions were sought: (1) How are the distributions of social skills included in the stories for children aged three to six to their frequency? (2) What are the social skills included in the stories for children aged three to six? (3) How are the distributions of social skills included in the stories for children aged three to six according to their dimensions?

\section{Method}

This study is a qualitative research and is conducted in embedded single case design. Criterion sampling, which is a purposive sampling method, was used to determine the study group. In this line, the study group consists of 60 storybooks in total, which were published by various publishing companies, for children aged three to six, between the years 2009 and 2019. Content analysis method was adopted to analyze the data collected by means of document review. The data collected in this scope was analyzed by means of (1) coding data, (2) finding themes, (3) organizing and describing data according to codes and themes, and (4) interpreting the findings.

\section{Results}

It was seen that all of the stories in the study group are handled to support some of the social skills positively, while some of the stories are handled to support social skills negatively in any way. The existence frequency of the social skills the development of which would be supported positively in each of the stories in the study varies from 1-2 to 9 and above. In this framework, the rate of social skills that were positively supported predominantly in a story corresponds to 3-4 social skills. Nevertheless, the existence frequency of the social skills the development of which would be supported negatively in the stories varies from 1-2 to 3-4. The social skills of accepting ones' mistake and thanking are emphasized in the stories mainly, followed by the social skills such as helping and expressing ones' feelings and thoughts, and besides apologizing and playing together. It was also found that the other social skills in this scope include making friends, making decisions independently, get others' opinions when necessary, saying "please" when 
necessary, dealing with fears, agreement, listening carefully, taking the role of leader, being respectful, being attentive to study/work, being cheerful to others, being eager to try new things, and believing in oneself, etc. at lower rates. The social skills that are included in the stories at the lowest rate include convincing others of a favorable situation, making efforts to learn something one wonder about, relieving others when necessary, being brave, saying "no" when necessary, adapting to new situations, keeping promises, and defending oneself when necessary, etc. It was seen in the study findings that the social skills included in the stories are mainly in the dimension of "communication", then the dimension of "prosocial behaviors", followed by the dimension of "accommodation", while it was revealed that the social skills in the dimension of "assertiveness" is at a quiet lower rate and the dimension of "self-control" is rare.

\section{Conclusion and Discussion}

It was concluded in the study that the expressions in the stories handled in the study group, which support social skills positively, are higher; however, the expressions in some of the stories should be revised in this sense. It is thought that sharing the plot fictions of the stories with the audience children naturally brings along messages such as establishing communication, asking questions, express oneself, helping, and thanking, and this may bring in more gains in this direction. These are supported by the results of some of the studies (Angin and Soydan, 2017; Dirican and Dağlığlu; 2014; Turan and Ulutaş, 2016). In one of the stories, it was found that there are expressions that suggests a didactical manner, stating a child that he is punished as he does not know the real magical words, as a situation to teach the social skills such as thanking and apologizing; while it was seen in another story that child is involved in the plot with a reproving expression. It will be better to adopt processes in which children can see that their behavior is not a proper behavior, instead of trying to teach children a skill with such expressions. It was found in a story that it contains the expression of shouting; and in another story, which is a translated literary work, the reactions containing the situations of inability to control anger, not being kind to others, and not being tolerant with others are highlighted. Similar results were emphasized in the studies by Dağlıoğlu and Çamlıbel Çakmak (2009) and also Firat, Güleç, and Şahin (2013). Similarly, in another story, while it was tried to teach children that they should be clean, the message that they should use a proper discourse while communicating with others is ignored. It is essential that preschool children stories reveal sample cases equivalent to the reality of children. The command sentences in one of the stories cause children to face conditional acceptance. As long as such judgments are repeated, they can lose their edges and prevent children from thinking in cause and effect relationship. In fact, the cases of lives suitable for children fictionalized by the authors in children's books should give rise to questions that should be answered in the minds of children (Sever, 2003). The expression of “don't be stupid” in a story supports children to feel a violent word. Dağlığlu and Çamlıbel Çakmak (2009) as well as Öztürk and Giren (2016) emphasized that the words related to excessive magic factors and mysterious events to be a fear factor in storybooks for preschool children should be avoided. Social skills from the dimension of communication such as expression, asking questions, and answering questions, and from the dimension of prosocial behaviors such as thanking, helping, apologizing, and being kind to others are delivered in a much more natural manner in stories, which support the result 
of the study of Aksoy (2014). Stories for preschool children should be enriched in terms of social skills such as acting independently, self-confidence, being brave, showing leadership, defending the right, coping with fearful/worrisome situations and controlling their anger and the factors that stories have in terms of social skills should be taken into consideration among the story selection criteria for target group. In future studies, story sets published by different publishing companies can be addressed with a holistic approach and comparative evaluation of the stories in the context of subjects, content, themes and so on, can be carried on a wider sample. 


\section{GİRİŞ}

Okul öncesi dönem çocuklarının oynama, eğlenme ve öğrenme gereksiniminden yola çıkarak, bu gereksinimlerini karşılayacak araçlara büyük önem duyulmaktadır. Bu araçlardan biri hem görsel hem de dilsel niteliği ile çocuğun oynama, eğlenme; görme, duyma, dokunma yoluyla tanıma ve keşfetme gereksinimini karşılayan kitaplar olmaktadır. Bu kapsamda kitapların çocuğun kavram gelişimine ve anlama becerisine katkı sağlayıcı bir yönü vardır. Okul öncesi dönemdeki çocukların öğrendikleri yeni kavramları adlandırma ve bunlar arasında ilişkileri kurma şeklindeki bilişsel süreçler kitaplarla işletilmektedir. Okul öncesi dönemde bir yetişkin tarafindan okunan ve çocuk tarafindan resimlerine bakılan kitaplar, yetişkin ile çocuk arasında fiziksel ve duyuşsal bir yakınlık oluşturmaktadır. Kitabın kendisine sunduğu dilsel ve görsel olanaklar ile yeni yaşantılar kazanmaya başlayan çocuk, sevdiği bir karakterle çeşitli paylaşımlar yaşamasına aracılık eden kitaba karşı sevgi ve sayg1 oluşturmaya başlamaktadır. Çocuğun ileriki yaşlarda okuma alışkanlığ1 becerisini edinebilmesi için de okul öncesi dönemde kitaba olan ilgi ve sevgisini oluşturmaya yönelik çabalara ihtiyaç duyulmaktadır (Sever, 2003). Okuma ve yazma bilmeyen okul öncesi dönem çocuğuna canlı renkleri, resimleri ve şekilleri ile görsel bir şölen sunan resimli kitaplar, çocukların harflerle, kelimelerle ve cümlelerle tanışmasına kaynaklık etmektedir (Oruç, 2010). Okul öncesi dönem çocuklarının çocuk edebiyatı eserleri ile buluşturulmasının gerekli olduğu görüşünden hareketle; öykü, masal, tekerleme, fabl, şiir, bilmece gibi farklı türlerdeki çocuk edebiyatı eserlerinin okul öncesi yıllarda önemli bir işleve sahip olduğu kabul edilen bir durum olmaktadır. Yazı ile çizginin sanatçı duyarlılığı ile buluşturulması sürecini içeren öykülerin varllğı da bu kapsamda okul öncesi dönem çocuklarının yaşamında ayrı bir öneme sahiptir.

Öykü, yaşanmış ya da yaşanması muhtemel olan olayların zaman, mekân ve kahraman bağlamında kısa biçimde anlatıldığı bir yazın türüdür. Öykü kitaplarının çocuklara duyumsatılması çocuğun kendini ve çevresini tanımasını sağlamakta, çevresiyle sağlıklı ilişkiler kurmasına yardımcı olmakta, algılama ve yorumlama yeteneğinin gelişmesine katkıda bulunmaktadır (Kaya Bağdaş ve Demir, 2016). Öykü kitaplarında yer alan yazılı metinler aracıllğıyla çocuklar gözlem yapma, inceleme ve öğrenme olanakları bulurken, metinleri destekleyen resimler aracılığıyla da anlama, kavrama, ilişki kurma ve duyumsama firsatı elde etmektedir. Bu bağlamda hitap ettiği yaş grubuna uygun olan öykülerin çocuk gelişim ve eğitimindeki katkısı çok yönlüdür. Öykü ile etkileşim sürecinin birtakım beceri ve davranışları çocuğa kazandırması söz konusu iken, öykü içerisinde yer alan anlatılar yoluyla çocukların sosyal yaşama hazırlanması ve birtakım sosyal davranışları öğrenmesi de olasıdır. Okul öncesi yaştaki çocukların erken okuryazarlık becerilerinin ve motivasyonlarının gelişiminde okuma etkileşimlerinin önemli olduğuna dikkat çekilmiştir (Sonnenschein ve Munsterman, 2002). Bebeklik 
döneminden başlayarak çocuklarla buluşturulan öykülerin çocuk üzerinde istenen etkiyi uyandırabilmesi için sahip olduğu unsurlar bağlamında nitelikli olması gerekmektedir.

Bu çerçevedeki eserlerin çocukların okul öncesi dönemden başlayarak farklılaşan bireysel ilgi ve gereksinimlerine yanıt verecek bir içerikte olması gerekmektedir. Çocukların yüreklerinde ve belleklerinde sevgi, dostluk, barış gibi nitelikleri edinme anlayışının gelişmesine katkı sağlaması esas bir durumdur. Öykülerde iyi kurgulanmış bir şekilde çocukların doğasına uygun olarak sunulan olaylar dizisi, çocukların hem kendi yaşamını ve birikimlerini tanımalarına olanak sağlamakta hem de sanatçı tarafindan kurgulanmış yaşam durumlarından yola çıarak yeni deneyimler edinmelerine firsat sunmaktadır. Çocukların öykülerde öykündükleri kahramanlar ve onların özellikleri ile özdeşim kurarak onun sözleri ve davranışları ile karşılaştı̆̆1 sorunlar karşısında çözümlerini örnek alması, onun gibi duymaya, düşünmeye ve hareket etmeye istekli olması söz konusu olmaktadır. Öykülerde çocuğun eğlenme, keşfetme ve hareket etme gerçeğine uygun karakterlerle karşılaşması sonucunda, karakterin çocuk üzerindeki izleri de kalıcı hale geçmeye başlamaktadır (Sever, 2003). Bu çerçevede teması, konusu, kahramanları, dil ve anlatımı gibi birtakım özellikleri itibariyle öyküde yer alan anlatıların nasıl olduğu önemli bir husus olarak ortaya çıkmaktadır. Bu özelliklerin nasıl olduğuna bağlı olarak da öykülerin çocuğun yaşamındaki yeri değişiklik gösterebilmektedir.

Okul öncesi dönem çocuklarına yönelik öykü kitaplarının çocuğa görelik ilkesi bağlamında içerdiği tümceler ve verdiği iletiler eşliğinde sosyal beceriler de yapılandırılmaktadır. Sosyal beceriler genel bir ifadeyle, bireyin etkili iletişim kurmasını ve kabul edilmeyen tepkilerden kaçınmasını sağlayan öğrenilmiş davranışlardır (Gresham ve Elliot, 1990). Çocuğun başkalarıyla olumlu sosyal ilişkiler kurması ve kurduğu ilişkileri sürdürebilmesi için ihtiyaç duyulan beceriler vardır (Stanley, 2009). Sosyal beceriler görevi yerine getirme, izin isteme, gruba dâhil olma, konuşmayı başlatma, arkadaşlarla birlikte oyun oynama gibi davranışları içermektedir (Elliott, Gresham, Frank, ve Beddow, 2008). Sözel ve sözel olmayan bir takım davranışları içeren sosyal becerilerin öğrenilmesi gözlem yapma, model alma ve rol oynama gibi yollarla gerçekleşmektedir (Michelson, Sugai, Wood, ve Kazdin, 1983). Çocuğun gelişim ve öğrenmesi açısından önemli olan sosyal becerilerin kazandırılması sürecinde, çocuğa içerdiği karakterler aracilığıyla özdeşim modelleri sunan ve çeşitlenmiş olay kurguları aracığıyla farklı bakış açısı kazandıran öykülerin payı büyüktür. Justice ve Kaderavek'in (2002) çocuğun öykülerle sözlü ve görsel olarak etkileşim kurmakta olduğunu belirtmesi de yeni deneyimler elde etmesi, kendisinin ve başkalarının duygularını anlaması ve tepkilerini düzenlemesi noktasında katkı sağlayıcı olduğunun bir göstergesidir. 
Öykünün sosyal beceriler üzerindeki etkisini vurgulayan Yurtseven ve Kurt'un (2013) çalışması, öykünün okunma sıklığı ile öykü seçimindeki yeterliliklerin çocukların sosyal becerileri üzerinde etkili olduğunu ortaya koymuştur. Hikâye temelli eğitim programının anasınıfina devam eden çocukların sorumluluk ve işbirliği becerileri üzerindeki katkısını ele alan Baş’ın (2011) bulguları da bu noktada dikkat çekicidir. Hikâye temelli eğitimin sosyal beceriler üzerinde katkı sağlayıcı olduğu Aksoy'un (2014) çalışmasında da açı bir şekilde dile getirilmiştir. Okul öncesi eğitimde sosyal beceri eğitiminin öykülerle desteklenmesinde öğretmenlerin öyküleri sürece dâhil etmesi öncelikli bir durum olurken, dâhil edilen öykülerin içeriğinde sosyal becerileri destekleyici unsurların yer alması da gerekli bir durumdur. Okul öncesi eğitimde öğretmenlerin gün içerisinde genel olarak en az bir öykü kitabı okudukları ve sınıfta okuyacakları öykü kitaplarını daha çok içeriğine göre tercih ettikleri bilinmektedir (Turan ve Ulutaş, 2016). Buna karşın, okul öncesi dönem çocuklarına yönelik öykülerin sosyal beceri eğitimini ele alma durumlarının nasıl olduğu ve öykülerin sosyal becerileri yapılandırma şekillerinin ne yönde olduğu esas önemli olan kısımdır. Bu duruma ilişkin bir kanıya varılmasında, öykü kitaplarında yer alan sosyal becerilere ilişkin bir değerlendirmenin yapılması önemli bir adım olacaktır.

Alanyazında yer alan ulusal çalışmalarda okul öncesi öğretmenlerinin öykü kitapları hakkında görüşleri (Kaya Bağdaş ve Demir, 2016) ile bu kitapları kullanma durumları (Turan ve Ulutaş, 2016) ve okul öncesi öğretmen adaylarının resimli öykü kitaplarını seçme konusundaki yeterlilik düzeyleri (Turan, Gönen, ve Aydos, 2017) değerlendirilmiştir. Okul öncesi öğretmenleri bilgi ve bilinç düzeyine sahip olduklarında öykülerin çocukların gelişimleri üzerindeki etkisini kabul etmesi söz konusu olurken, öyküleri çocukların gelişimlerini destekleyecek bir kaynak olarak kullanabilmeleri noktasında okul öncesi döneme ait öykülerin içerikleri önemli olmaktadır. Bu kapsamda yapılan çalışmalar arasında okul öncesi dönem çocuklarına yönelik resimli öykü kitaplarında yer alan korku ve şiddet öğelerinin (Dağlığlu ve Çamlıbel Çakmak, 2009; Fırat, Güleç, ve Şahin, 2013, Öztürk ve Giren, 2016), mizahi unsurların (Akınc1, 2015), kavram ve becerilerin (Angin ve Soydan, 2017), oyuncakların (Dilek, 2017), baba figürünün (Bencik Kangal, Karaaslan, ve Arslan, 2018), fen kavramlarının (Alptekin, 2018), çevre eğitimi konularının (Güzelyurt ve Özkan, 2019), yaşl1lık kavramının (Korkmaz, Koyuncu Şahin, ve Gönen, 2018) ve sözsüz kitap anlatımlarında yer alan hikâye elementlerinin (Yekeler ve Cengiz, 2018) incelenmesine yönelik çalışmalar mevcuttur. Okul öncesi dönem çocukları için resimli çocuk kitaplarında yer alan değerler (Dirican ve Dağlıŏlu, 2014; Körükçü, Acun Kapıkıran, ve Aral, 2016) ile hikâye ve masallarda yer alan değerler (Cengiz ve Duran, 2017) ve değer eğitimi konusunda anaokullarının sınıf kitaplıklarında bulunan öykü kitapları (Bildirici ve Bulut Pedük, 2017) farklı çalışmalarda konu edinilmiştir. Okul öncesi öykü 
kitaplarının okunabilirlik (Çeçen ve Aydemir, 2011) açısından incelendiği ve ayrıca resimli çocuk kitaplarının resimleme özelliklerinin (Yıldız, Yazıcı ve Durmuşoğlu, 2016) ele alındığı çalışmalara da rastlanmıştır. Bu çerçevede öykü kitaplarının sosyal becerilere yer verme durumlarını ele alan ve öykü kitaplarındaki sosyal becerileri ortaya çıkaran herhangi bir çalışmaya rastlanmamıştır. Bu çalışma kapsamında Türkçe olarak yazılmış veya Türkçe'ye çevirisi yapılmış farklı yayınevleri tarafından yayınlanmış okul öncesi dönem çocuklarına yönelik öykü kitaplarında yer alan sosyal becerilere ilişkin sonuçların, sosyal becerileri desteklemek üzere öykülere başvuran öğretmenlere, ebeveynlere, yazar, çizer ve yayınevi olarak hizmet veren kişi veya kurumlara katkı sağlaması beklenmektedir.

\section{Amaç}

Bu çalışmada temel olarak, üç-altı yaş çocuklarına yönelik öykülerin sosyal beceriler açısından incelenmesi amaçlanmıştır. Bu temel amaç doğrultusunda, aşağıdaki sorulara yanıt aranmıştır.

1. Üç-altı yaş çocuklarına yönelik öykülerde sosyal becerilerin yer alma sayılarının sıklıklarına göre dağılımları nasıldır?

2. Üç-altı yaş çocuklarına yönelik öykülerde yer alan sosyal beceriler nelerdir?

3. Üç-altı yaş çocuklarına yönelik öykülerde yer alan sosyal becerilerin ait oldukları boyutlara göre dağglımları nasıldır?

\section{YÖNTEM}

\section{Araştırmanın Modeli}

Okul öncesi dönem çocuklarına yönelik öykü kitaplarının sosyal beceriler açısından incelenmesi esasına dayanan bu araştırma, nitel çalışma türünde bir araştırmadır. Araştırmada durum çalışması deseni kullanılmıştır. Durum çalışmasında, belirli bir duruma ilişkin sonuçları ortaya koymak amaçlanmaktadır. Nitel durum çalışmasında temel olarak bir ya da birkaç durum derinliğine araştırılmaktadır. Bir diğer anlatımla, bir duruma ilişkin etkenler (ortam, bireyler, olaylar ve süreçler vb.) bütüncül bir yaklaşımla araştırılmakta ve ilgili durum üzerindeki etkilerinin nasıl olduğu üzerine odaklanılmaktadır (Fraenkel, Wallen ve Hyun, 2012; Yıldırım ve Şimşek, 2008) Nitel araştırma türündeki bu çalışmada, iç içe geçmiş tekli durum desenine başvurulmuştur. Burada çalışma kapsamına dâhil edilmiş olan öykülerde yer alan sosyal beceriler ele alınırken, incelenen öykülerin farklı yayınevleri tarafından basılan öykülerden oluşması sağlanmıştır. 


\section{Çalışma Grubu}

Çalışmanın amacina uygun olacak şekilde çalışma grubunun belirlenmesinde, amaçlı örnekleme yöntemlerinden ölçüt örnekleme yönetimi kullanılmıştır. Amaçlı örnekleme yöntemi, bilgi açısından zengin durumların seçilerek araştırma yapılmasına olanak sağlamaktadır. Ölçüt örnekleme yöntemindeki veri toplama birimleri belirli niteliklere sahip kişilerden, olaylardan, nesnelerden veya durumlardan oluşturulabilmektedir (Büyüköztürk, Kılıç Çakmak, Akgün, Karadeniz ve Demirel, 2018). Ölçüt örneklemedeki temel anlayış, önceden belirlenmiş bir dizi ölçütü karşılayan bütün durumların çalışılmasıdır. Çalışmaya temel oluşturan ölçüt bir ölçüt listesinden yola çıkarak belirlenebileceği gibi, araştırmacı tarafından da oluşturulabilmektedir (Yıldırım ve Şimşek, 2006). Çalışmanın araştırmacı tarafindan belirlenmiş olan örneklem ölçütü ise çalışmaya dâhil edilecek olan öykülerin üç-altı yaş okul öncesi dönem çocuklarına yönelik olması ve 2009-2019 yılları arasında yayınlanmış öykülerden olmasıdır. Bu doğrultuda, öncelikle araştırmacı tarafindan internet web sayfalarında ve yayınevi tanıtım kataloglarında çocuk öyküleri kapsamında ulaşılır olan okul öncesi dönem çocuklarına yönelik öykü kitaplarının taraması yapılmıştır. Farklı yayınevleri tarafından 2009-2019 yılları arasında yayınlanmış olan okul öncesi dönem çocuklarına yönelik öykülerden tesadüfi örnekleme yöntemi ile birer öykü temin edilmiş ve bunlar çalışma amacı doğrultusunda değerlendirilmek üzere çalışma kapsamına dâhil edilmiştir. Bu doğrultuda, çalışma grubunu 20092019 yılları arasında okul öncesi dönem çocukları için farklı yayınevleri tarafından yayınlanmış öykü kitaplarından birer öykü kitabı olmak üzere toplamda 60 öykü kitabı oluşturmaktadır. Çalışma kapsamına dâhil edilen öykü kitaplarının \% 85’i (f=51) Türk yazarlar tarafından yazılmış olan öykü kitapları iken; \%15'i (f=9) çeviri kitaplardır. Çalısma grubunda yer alan öykülerin büyük bir k1sminda ( $\mathrm{f}=41$ ile $\%$ 68.33) yer alan karakterler de hayvan karakterleridir.

\section{Verilerin Toplanmas1}

Nitel araştırma türündeki bu çalışmanın verilerinin toplanmasında, doküman incelemesi yöntemine başvurulmuştur. Doküman incelemesi, araştırılması hedeflenen bir olgu hakkında bilgi içeren yazılı materyallerin analizini içermektedir. Dokümanlar, nitel araştırmalarda etkili bir şekilde kullanılması gereken önemli bilgi kaynaklarıdır. Bu tür araştırmalarda, araştırmacının ihtiyacı olan veriyi, gözlem veya görüşme yapmaya gerek kalmadan elde etmesi söz konusudur (Yıldırım ve Şimşek, 2008). Bu çalışmanın dokümanını, okul öncesi dönem çocukları için 2009-2019 yılları arasında farklı yayınevleri tarafından yayınlanmış ve çalışma kapsamına dâhil edilmiş olan 60 farklı öykü kitabı oluşturmaktadır. Bu öykü kitapları çalışma amacı eşliğinde araştırmacı tarafından birebir okunmuş ve içerisinde yer alan sosyal beceri ifadeleri analiz edilmek üzere düzenlenmiştir. 


\section{Verilerin Analizi}

Çalışmada elde edilen verilerin analizinde, içerik analizine başvurulmuştur. İçerik analizinde toplanan verileri açıklayabilecek kavramlara ve ilişkilere ulaşmak amaçlanmaktadır. Betimsel analizde özetlenen ve yorumlanan veriler, içerik analizinde daha derin bir işleme tabi tutulmakta ve betimsel bir yaklaşımla fark edilmeyen kavram ve temalar içerik analizi sonucu ortaya konmaktadır. Bu doğrultuda toplanan verilerin önce kavramlaştırılması ve daha sonra da ortaya çıkan kavramlara göre mantıklı bir biçimde düzenlenmesi ve buna göre veriyi açıklayan temaların saptanması gerekmektedir Bu sayede içerik analizinde veriler tanımlanmaya ve verilerin içinde saklı olabilecek gerçekler ortaya çıkarılmaya çalışılmaktadır. Temel olarak içerik analizinde, birbirine benzeyen veriler belirli kavramlar ve temalar çerçevesinde bir araya getirilmekte ve bunlar okuyucunun anlayabileceği bir biçimde düzenlenerek yorumlanmaktadır (Fraenkel, Wallen ve Hyun, 2012; Yıldırım ve Şimşek, 2008). Elde edilen verilerin içerik analizi dört aşamada gerçekleştirilmiştir.

1. Verilerin kodlanması: Bu aşamada öykü kitaplarından elde edilen bilgiler incelenerek, anlamlı bölümlere ayrilmaya ve her bölümün kavramsal olarak ne anlam ifade ettiği belirlenmeye çalışılmıştır. Ayrıca çalışma kapsamına dâhil edilen öykülerin her birine Ö1 (Öykü 1), Ö2 (Öykü 2), Ö3 (Öykü 3) ... Ö60 (Öykü 60) şeklinde bir kod isim verilmiş ve çalışmada gerekli yerlerde öykülerin isimleri yerine kod isimleri kullanılmıştır. Öykülerde yer alan sosyal beceri kelimeleri ve/veya cümleleri araştırmacı tarafından isimlendirilmiş ve bunlar her bir öykü için sosyal beceri kodları olarak kaydedilmiştir. Buradaki kodlamalar sosyal beceri davranışının ifade edilişine göre bazen bir sözcük bazen de birden fazla sözcük ile ortaya konmuştur. Bu aşamada öykülerdeki metinlerde geçen ifadelere göre uygun kodların belirlenmesine özen gösterilmiştir. Çalışma kapsamına dâhil edilen öykülerin her biri için kodlamalar yapıldıktan sonra, bir kod listesi yani sosyal beceriler listesi ortaya çıkmıştır. Bu liste de verilerin incelenmesinde ve düzenlenmesinde anahtar liste olarak görev yapmıştır. Bu sayede farklı öykülerde öne çıkan ortak sosyal beceriler, aynı kodlarla isimlendirilmiştir. Öykülerde mevcut olan metinlerin kodlanması sürecinde çalışma amacı göz önünde bulundurulmuştur. $\mathrm{Bu}$ yolla araştırmada geçerli sonuçlara ulaşılması hedeflenmiştir. Kodlamada kullanılan sosyal beceri kavramlanının seçiminde, öyküde geçen anlatımı veya olayı en iyi temsil eden sosyal becerinin ne olduğu ile bu becerinin alanyazınında hangi sosyal beceri altında ifade edildiği değerlendirilmiştir. Öykülerde geçen ifadelerde birden fazla sosyal becerinin harekete geçirilmesinin mümkün olduğu durumlarda, ilgili öykü için bahsi geçen her bir sosyal beceriye yönelik kodlama yapılmıştır. Buna göre; çalışmada tümevarımcı bir yaklaşımla çalışma grubundaki öykülerden çıkarılan kavramlara (sosyal 
becerilere) göre kodlama yapılmıştır. Buradaki kodlamalar da çalışmanın birinci ve ikinci alt amacında yer alan sorulara yanıt bulunmasını sağlamıştır.

2. Temalarm bulunması: $\mathrm{Bu}$ aşamada, analizin ilk aşamasında ortaya çıkan kodlardan yola çıkarak verileri, genel düzeyde açıklayabilen ve kodlan belirli kategoriler altında toplayabilen temaların (boyutların) bulunması üzerinde durulmuştur. Bunun için önce sosyal beceri kavramları için yapılmış kodlar bir araya getirilmiş ve kodlar arasındaki benzerlikler ve farklılıklar incelenmiştir. Tematik kodlama yaparken (iç tutarlılık için), ortaya çıkan verilerin altında yer alan verilerin anlamlı bir bütün oluşturup oluşturmadığı ve (dış tutarlılık için) ortaya çıkan temaların tümünün araştırmada elde edilen verileri anlamlı bir biçimde açılkayıp açıklayamadığı göz önünde bulundurulmalıdır (Yıldırım ve Şimşek, 2008). Bu çerçevede veri setine göre temaların belirlenmesi sürecinde yapılan değerlendirmelerde, Aksoy (2014) tarafindan geliştirilmiş olan Sosyal Becerileri Değerlendirme Ölçeği’nde yer alan boyutların kodlar için etkili bir şekilde işleyen temalar olduğu sonucuna ulaşılmıştır. Buna dayanarak, geçerli ve güvenilir olduğu tespit edilen ölçme aracının veri setini yansıtan temalar/boyutlar olarak kullanılması uygun görülmüş̧ür. Bu aşamada bulgulara dâhil edilmesi için öykülerde yer alan metinlerden bazı örnekler de seçilmiştir. Buradaki temalar/boyutlar da çalışmanın üçüncü alt amacına yönelik soruların cevaplanmasını sağlamıştır.

3. Verilerin kodlara ve temalara göre düzenlenmesi ve tanmmlanmasi: $\mathrm{Bu}$ aşamada ise araştırmacı tarafindan elde edilen verilerin düzenlenmesi sağlanmıştır. Bu kapsamda verilerin anlaşılır bir dille tanımlanmasına, açıklanmasına ve sunulmasına özen gösterilmiştir. Öykülerdeki metinlerin çeşitli bölümlerinde aynı kod ya da tema/boyut altında yer alan sosyal beceriler tanımlanmış ve ortaya çıan sosyal beceriler kavram ya da temaya göre birbiriyle ilişkili bir biçimde sunulmuştur. Bu aşamada toplanmış bilgiler, araştırmacının kendi görüş ve yorumlarından arındırılmış bir şekilde doğrudan ortaya konmuştur. Verilerin kodlara ve temalara/boyutlara göre düzenlenmesi araştırmacı tarafından gerçekleştirildikten sonra, farklı bir zamanda (yaklaşık iki hafta sonra) yeniden değerlendirilerek güvenilir sonuçlara ulaşılması hedeflenmiştir. Araştırmacının kendisi tarafından düzenlenmiş olan sosyal beceri kodlarının ve temalarının/boyutlarının okul öncesi eğitimi alanında doktora derecesine sahip bir başka kişi tarafindan gözden geçirilmesi sağlanmış ve bu çerçevede sadece dört farklı öyküde yer alan birer sosyal becerinin kodlanmasında bir fikir ayrıllı̆̆ının olduğuna rastlanmıştır. Bu çerçevede, Miles ve Huberman'ın (1994) formülüne göre (Güvenirlik= Görüş birliği/ Görüş birliği + Görüş ayrillğı $1 \% 93$ ile iyi düzeyde güvenilir verilere ulaşıldığ1 
sonucuna ulaşılırken, bu durumların görüldüğü ifadeler yeniden gözden geçirilerek uygun görülen kodlama altında düzenlenmiştir.

4. Bulgularm yorumlanması: $\mathrm{Bu}$ aşamada da ayrıntılı bir biçimde tanımlanan ve sunulan bulgular araştırmacı tarafindan yorumlanmış ve çalışmadan elde edilen sonuçlar ortaya konmuştur. Bu kapsamda araştırmacı çalışma bulguları arasındaki neden-sonuç ilişkilerini açıklamaya ve bulgulardan yola çıkarak sonuçları açıklamaya özen göstermiştir. Elde edilen sonuçların öneminden yola çıkarak birtakım öneriler de ileri sürülmüştür.

\section{BULGULAR}

Bu bölümde çalışma amacı doğrultusunda elde edilen bulgular tablolar dâhilinde ortaya konmuştur. Çalışmanın birinci alt amacına yönelik olarak, üç-altı yaş çocuklarına yönelik öykülerde sosyal becerilerin yer alma sayılarının sıklıklarına ilişkin bulgular Tablo 1'de ve çalışmanın ikinci ve üçüncü alt amacına yönelik olarak, üç-altı yaş çocuklarına yönelik öykülerde yer alan sosyal becerilere ve bu sosyal becerilerin ait oldukları boyutlara ilişkin bulgular da Tablo 2'de sunulmuştur.

Tablo 1. Öykülerde yer alan sosyal beceri sayılarının sıklıklarına göre frekans ve yüzde dağılımları

\begin{tabular}{lcc}
\hline Öyküler içerisinde olumlu yönde desteklenen toplam sosyal beceri sayısı & $\mathbf{f}$ & $\mathbf{\%}$ \\
\hline 1-2 sosyal beceri & 5 & 8.33 \\
\hline 3-4 sosyal beceri & 25 & 41.66 \\
\hline 5-6 sosyal beceri & 14 & 23.33 \\
\hline 7-8 sosyal beceri & 12 & 20.00 \\
\hline 9 ve üzeri sosyal beceri & 4 & 6.66 \\
\hline Toplamı & $\mathbf{6 0}$ & $\mathbf{1 0 0 . 0 0}$ \\
\hline Öyküler içerisinde olumsuz yönde desteklenen toplam sosyal beceri sayıs1 & $\mathbf{f}$ & $\mathbf{0}$ \\
\hline 1-2 sosyal beceri (-)* & 6 & 10.00 \\
\hline 3-4 sosyal beceri (-)* & 2 & 3.33 \\
\hline Toplam1 & $\mathbf{8}$ & $\mathbf{1 3 . 3 3}$ \\
\hline
\end{tabular}

*(-); öykü içerisinde olumsuzyönde desteklenen sosyal becerileri temsil etmektedir.

Tablo 1 incelendiğinde, çalışma grubundaki öykülerin tamamında (60 öykü) bir kısım sosyal becerilerin olumlu yönde desteklenmesi sağlanacak bir şekilde ele alındığı ve birkaçında (8 öykü) da sosyal becerilerin olumsuz yönde desteklenmesi sağlanacak şekilde yer aldığı görülmektedir. Buna göre, çalısma kapsamındaki öykülerin her birinde gelişimi olumlu yönde desteklenen sosyal beceri sayılarının en az 1'den ve en fazla 9 ve üzerine kadar değişen sayılarda olduğu görülmüştür $\mathrm{Bu}$ çerçevede bir öyküde olumlu yönde desteklenen sosyal beceri sayısının ağırlıklı olarak (\% 41.66) 34 sosyal beceri olduğu tespit edilirken; olumlu yönde en az yoğunlukta (\% 6.66) yer alan sosyal beceri sayılarının ise 9 ve üzeri şeklinde olduğu sonucuna ulaşılmıştır. Her bir öyküde en az 1 türden sosyal becerinin olumlu yönde desteklenmesine yönelik bir sürecin yer aldığ1 görülmekle birlikte, bir grup (\% 8.33) öyküde yalnızca 1-2 adet sosyal becerinin ele alınmış olduğu da belirlenmiştir. 
Buna karşın, öykülerin içerisinde (nazik olmayan konuşmalar/davranışlar, şiddet içerikli öğeler ve aşağılayıc1/yargılayıcı yaklaşımlar ile) gelişimi olumsuz yönde desteklenecek bir şekilde ele alınan sosyal becerilerin yer alma sayılarının 1-2 ile 3-4 arasında değişiklik gösterdiği saptanmıştır. Bu kapsamda öykülerde olumsuz yönde desteklenen sosyal beceri sayıları ise 1-2 sosyal beceri üzerinde yoğunluk (\% 10) göstermiştir.

Tablo 2'de çalışma grubundaki öykülerde yer alan sosyal becerilerin neler olduğuna ve bunların ait oldukları boyutlara ilişkin dağılımlar görülmektedir. Buna göre, öykülerde farklı boyutlar altında yer alan toplamda 58 çeşit sosyal becerinin yer aldığı belirlenmiştir. Bunlar arasında yoğunlukla işlenen sosyal becerilerin hatasını kabul etme ile teşekkür etme ( $\mathrm{f}=19$ ), akabinde yardım etme ile duygu ve düşüncelerini ifade etme ( $f=18$ ) ve ayrıca özür dileme ( $f=17)$ ve bunu takiben birlikte oyun oynama ( $f=15)$ gibi beceriler olduğu saptanmıştır. Bu kapsamda öykülerde en az sayıda ( $f=1$ ) ele alınan sosyal becerilerin ise gerektiğinde 'hayır' deme, güçlü ve zayıf yönlerinin farkında olma, oyuna davet etme, jest ve mimiklerini uygun bir şekilde kullanma, bir şeyi rica ederek isteme, plan yapma, çevreyi koruma, yeni durumlara uyum sağlama, verdiği sözü tutma, cesur olma ve kendini savunma gibi beceriler olduğu belirlenmiştir. Çalışma grubundaki öykülerde ele alınan sosyal becerilerin ait olduğu boyutlara göre dağılımları için Tablo 2'ye bakıldığında; ele alınan öykülerde işlenen sosyal becerilerin ağırlıklı olarak (\% 41.38) "iletişim” boyutundan ve akabinde (\% 25.86) "prososyal davranışlar" boyutundan sosyal beceriler olduğu görülürken, bu sırayı "uyum” boyutundan (\% 18.97) sosyal becerilerin takip ettiği bulgusuna da ulaşılmıştır. Bunlara ek olarak, öykülerde çok daha azınlıkta bir oranda (\% 8.62) "atılganlık" boyutundan sosyal becerilerin ve nadiren (\% 5.17) de "kendini kontrol" boyutundan sosyal becerilerin ele alındığı belirlenmiştir. Bu bulgu, ele alınan öykülerde "iletişim" ve "prososyal davranışlar" boyutundan sosyal becerilerin yer alma olma olasılığının daha yüksek düzeyde olduğunu ifade etmektedir. Çalışma kapsamında yer alan öykülerde tespit edilen sosyal becerilere ilişkin örnek durumlar/ifadeler ortak boyutlar altında sırayla aşağıda açıklanmıştır.

Çalışma grubundaki öykülerde “iletişsim” boyutu altında çok çeşitli türden sosyal becerilerin yer aldığ1 dikkat çekmiştir. Bu kapsamda duygu ve düşüncelerini ifade etme, birlikte oyun oynama, soruna yönelik bir çözüm bulma, karşılaşma ifadesini kullanma ve anlamadı̆̆ı bir durum olduğunda soru sorma gibi sosyal becerilerin belirgin bir şekilde daha fazla ele alındığı görülürken, öğrenmek için çabalama, gerektiğinde 'hayır' deme, güçlü ve zayıf yönlerinin farkında olma, oyuna davet etme, jest ve mimiklerini uygun bir şekilde kullanma ve bir şeyi rica ederek isteme gibi sosyal becerilerin de 
Tablo 2. Öykülerde yer alan sosyal becerilere ve boyutlarına göre frekans ve yüzde dağılımları

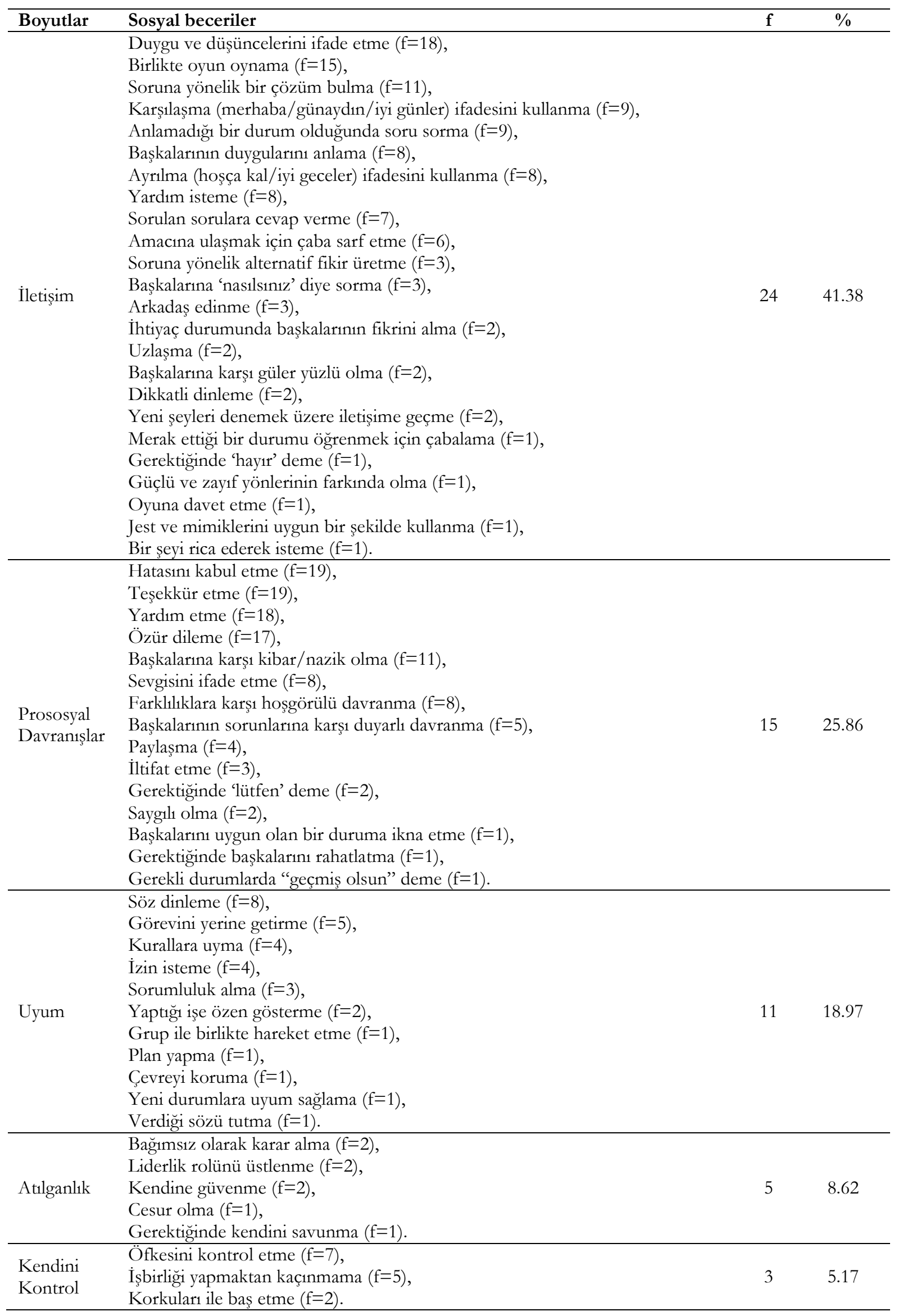


nadiren işlendiği saptanmıştır. Bu kapsamdaki örnekler değerlendirildiğinde; Ö1'deki öyküde ayının tavşanı görünce "Kaybolduğu için ü̊gün görünüyor" diye düşündügünün belirtilmesi başkalarının duygularını anlamayı içeren bir ifadedir. Ö2'de bir karakterin “Imdat! Düşüyorum. Yardim edecek kimse yok mu?" veya "Ne olursun, kuş kardeş bana yardım et! Nasıl uçtuğunu bana da ögret" diye seslenmesiyle ihtiyaç durumunda yardım isteme becerisi desteklenmektedir. Ö4'de "Hemen arkadaşlarnı kurtarmak için çalıșmaya başladılar. Kova koca su taşızı yangın söndürmeye çabaladılar... Yangın elbirliği ile bütün hayvanlarn çabasıyla söndürüldü” ifadeleriyle amacına ulaşmak için çaba sarf etmesi gerektiği yönünde bir durum öne çıkmaktadır. Ö9'daki öyküde çocuğun babasına "Sarmaşıklar duvara tırmanabilirler mi??” sorusunu sorması ve babasının ona sarmaşığın küçük kökçüklerini göstererek bunların tutucu kökçükler olduğunu açıklamasının ardından “Nasıl yani! Örümcekler gibi mi?” gibi sorular sormasıyla anlamadığı bir şey olduğunda soru sorabileceği yönünde bir durum teşvik edilmektedir. Ö13'de ise öykü karakterlerinden kuşun ayağına batan dikeni çıkarması için arkadaşından yardım istemesi ve arkadaşıyla birlikte dikeni çıkarması ile öykü sonlandırılmıştır. Aynı öyküde kuşun kendi kendine düşünerek, "Herkes ötüsümden yakmıyor. Belki de hakhdırlar biraz daha sessiz olmalyym" demesi iletişim boyutunda yer alan başkalarının duygularını anlama becerisi için bir adımdır. Bunlara ek olarak, Ö23 eserinde ördeğin sinirli halleri karşısında arkadaşlarının ondan uzak durduğu ve onu görünce saklandığı; sonrasında ördeğin tek başına çok canı sıkıldığı şeklinde bir kurguyla sinirli olmanın arkadaş edinmeye zarar verdiği ile ilgili iletiye yer verilmiştir. Bu sayede öfkesini kontrol etme ve çevresindekilere sıcak davranma yönündeki sosyal becerilere değinilmiştir. Ancak Ö34'de yer alan "Neredesin kardeşim! diye bağırmaya başladi" tümcesinde geçen bağırma ifadesi yerine seslenme şeklinde bir sözcüğün tercih edilmesi şiddet içerikli anlatımdan uzaklaşılmasına yardımcı olabilir. Yine Ö35'de "Güzel resim çizmeye çalısıyor, ama beceremiyordu”, "Resim kâğ̌dın burușturup odanın diğer köșesine firlattı", "Ne istiyorsun? diye tersledi", "Onlar bana getir! diye bağırdı" şeklinde öfkesini kontrol edememeye, başkalarına karşı kibar/nazik olmamaya ve başkalarına karşı hoşgörülü olmamaya dair örnek anlatımlar yer almaktadır. Bu öykünün çeviri bir eser olması da ayrıca dikkat çekici olmuştur.

Öykülerde "prososyal davranıslar" boyutu altındaki sosyal beceriler arasında hatasını kabul etme, teşekkür etme, yardım etme, özür dileme ve başkalarına karşı kibar/nazik olma gibi becerilerin daha fazla yer alırken; gerektiğinde 'lütfen' deme, saygılı olma, başkalarını uygun olan bir duruma ikna etme ve gerektiğinde başkalarını rahatlatma gibi becerilerin ise daha az yer aldığı görülmüştür. Bu boyut altındaki sosyal becerilere ilişkin örneklere bakıldığında; Ö1'de "Ayı, kaybolan tavşancığgn kendisinin olmasm istemis ama ailesi tavşanciğı çok merak etmişstir diye düsünmü̈s" şeklindeki bir tümceden hareketle başlarının duygularını anlayarak yerine götürmeye karar vermesi ile soruna uygun bir çözüm yolu bulmanın gerekliliği duyumsatılmıştır. Bu kapsamda öne çıkan farklı birkaç öyküde de 
arkadaşlarından birinin yangın yeri içerisinde kalması, görme engelli çocuğun yürüme yolunda engellerle karşılaşması ve eşeğin çok ağır yüklerle yorulması gibi durumlardan yola çıkarak yapılan anlatımlarla başkalarının sorunlarına karşı duyarlı davranılması gerektiği iletisi verilirken, aynı zamanda soruna yönelik bir çözüm bulma becerisinin de işletildiği söylenebilir. Yine Ö4'de ördeğin “Bana yardımo olur musun?” talebi karşısında çiftlikteki bir hayvanın "Aman niye yardım edecekmişim ki?” şeklinde yanıtı üzerine "zavall bayan ördek ..." ifadesiyle anlatıma devam edilmesi, başkalarına karşı duyarlı olmamanın hoş karşılanan bir davranış olmadığı mesajını vermektedir. Ö9'da çocuğun sevgiyle sarmaşığın yapraklarına dokunması ve sarmaşığa şiir yazması eşliğinde de sevgiyi ifade etmeye ilişkin durumlara değinilmektedir. Ö40'da anne ve babanın düşen yavru kuşa “Bir şeyin yok ya?” diye sorması da başkalarının sorunlarına karşı duyarlı davranılması gerektiğini vurgulayan bir ifadedir. Ö42'de “Para benim nasıl istersem harcarm. Bu seni ilgilendirmę"” şeklinde sözlerin geçmesi ise başkalarına karşı nazik olmayan bir konuşma tarzının çocuk tarafindan duyumsanmasına aracılık edecek bir başka durumdur.

Öykülerde hatasını kabul etme, özür dileme, uzlaşma ve paylaşma gibi çeşitli sosyal becerilerin farklı senaryolar eşliğinde birçok öyküde ele alınmış olması da dikkat çekicidir. Örneğin; Ö11'de iki oyun arkadaşının oyunlarında kardan yapacakları hayvan konusunda uzlaşma sağlayamaması üzerine karşılaştıkları bir sorunun ardından birbirine zarar vermesinin sonucu olarak, karşlıklı olarak hatalarını fark edip özür diledikten sonra evde oyun hamurlarından birçok hayvanı yapmaya karar vermeleri şeklinde bir serüven yer almaktadır. Ö20'de karakterin, "Arkadaşlar öžür dilerim. Elmalar sahipsiz sandım ben aldım" demesi ile karakterin yanında üç elma getirmesi ve diğerlerine birer elma vermesi ile hep birlikte afiyetle yemelerini içeren anlatımların yer alması da paylaşma ve özür dileme içerikli becerilere vurgu yapan bir başka durumdur. Benzer bir şekilde Ö55'de arkadaşıyla balonunu paylaşmayan karakterin elinden balonun kaçıvermesinin ardından kaktüsün üstüne düşmesi ve patlaması sonucunda özür dilemesi ve balonu paylaşması gerektiğini ifade etmesi ile ilgili anlatımlar da özür dileme ve beraberinde paylaşma yönündeki becerileri öne çıkaran durumlardır. Çalışmada “prososyal davranışlar” boyutu altında daha azınlıkta görülen bir sosyal beceri örneği olarak da Ö48 içerisinde yer alan “...Ne güzel yapmışsın. Cok beceriklisin” ve Ö50 içerisindeki "Aferin sana... Ne kadar da becerikliymisssin... Kutlarm. Cok güzel oldu” şeklindeki ifadelerle iltifat etmeye değinildiği saptanmıştır. Bu boyut altında daha nadir olarak rastlanan sosyal becerilere ilişkin bir örnek olarak ise Ö6' da öyküdeki ana karaktere “Üzülme arkadaşım, neşelen birą̌”, şeklinde bir ifade eşliğinde onun kendini iyi hissetmesinin sağlanması ile başkalarını rahatlatma becerisinin harekete geçirildiği söylenebilir. Aynı öyküde “Neden benim vücudum yumusak, biç kemiğim yok” diye merak eden ahtapotun 
tüm ahtapotların böyle olduğunu öğrenmesi de merak edilen/bilinmeyen bir durumun öğrenilmesi gerektiğini duyumsatan bir diğer durumdur.

Çalışma kapsamındaki öykülerin bazılarında karakterler olumsuz sosyal beceriler sergilemelerinden kaynaklı olarak olumsuz durumlarla karşılaşmakta veya amacına ulaşamamakta ve böylece uygun olan sosyal becerilerin edinilmesi desteklenmektedir. Bu durumlara ilişkin bir örnek olarak; Ö17'de kurbağa bataklıklarda dolaşarak, mektupları 1slatarak okunmaz hale getirerek dağıttığ1 için mektupları alanların okumakta zorlandığı ve herkes leyleğin bir an önce iyileşmesini beklediği; sonunda ise iyileşen leyleğin görevinin başına geçmesiyle mektup yazmanın da almanın da çok güzel olduğu belirtilmiştir. Dolayısıyla, görevini gerektiği gibi yerine getirmeyen bireyin onaylanmadığ1 görüşü hâkimdir. Bu durumların aksine, birkaç öyküde yer alan tümcelerin bir kısmı bu anlamda olumsuz bir uyaran olarak görev yapacak türdendir. Örneğin; Ö52'de ve Ö53'de yer alan baz1 ifadelerde çocuğa ders verir gibi bir anlatımın benimsendiği ve eleştirel bir yaklaşımla uygun davranışa yönlendirmenin yapıldığı dikkat çekmektedir. Ö52'de geçen; “Üstelik bunlarn hiçbirini yapmamışken televiąyon i:leyeceğini söylüyorsun... Bundan böyle cumartesi ve pazar günleri kahvaltı sofrasmm hą̧rlanmasina yardım edeceksin... Sen de bir yetişkin gibi üzerine aldiğm görevleri yerine getirmelisin” gibi ifadeler bir kurgu içerisinde çocuğun doğru davranışı fark etmesini sağlamaktan daha ziyade beklenen davranışları doğrudan çocuğa sunmaktadır. Ö53'de ise "Kötü kalpli kurt onu suya itmişti" gibi bir ifadeyle farkl11lklara karşı hoşgörülü olma becerisine uygun olmayan ve çocukları önyarg1lı olmaya yönlendiren bir anlatım benimsenmiştir. Bu kapsamda Ö10'daki eserde de düşündürücü olan birkaç unsura rastlanmıştır. Öyküde yer alan "Hayvanlar seninle oynamaktan çok hoşlanırlar, ama onlara daima sevgiyle davranmalısın. Ëğer hayvanlara zarar vermęsen ve onlara karşı sayg̨l davranırsan, onlarn da sana saygll davranacaklarm hatırlaman için yanındayım" veya "Seni doktora götürdüklerinde orada sakin olmalısın. Hastalandiğznda ya da camın yandiğında iyileşmen için doktor ve ben hep senin yanındayız”, gibi emir cümleleri eşliğinde çocuğun nasıl davranması gerektiğinden bahsedilmekte ve bu koşullar sağlandığında çocuğun yanında olunacağı belirtilmektedir. Aynı öyküde çocuğun korkusu karşısında "Baban, seni okula buraktıktan sonra yalmız mı kaliyor sanyorsun? Hayır, tabii ki değill Aptallı etme” gibi bir ifadenin yer alması başkalarına karşı nazik davranma becerisinin sergilenmediği bir durumdur. Burada "aptallık etme" gibi nazik olmayan bir ifade ile korkunun yersiz olduğundan bahsedilmeye çalış1lırken, çocuğun düşüncesini alaya alma gibi bir durumun da söz konusu olduğu söylenebilir. Bu durum başkalarına karşı hoşgörülü davranma/başkalarının fikirlerine saygılı olma gibi becerilerle ters düşen bir durumdur. Bununla birlikte, Ö7'deki öyküde çocuğa (özür dileme gibi) gerçek sihirli sözleri bilmemesinden dolayı cezalı olduğu belirtilerek, kibar olmayı öğrenmesi gerektiğinin açıklanması ise durumun önemini hissettirmekten daha ziyade ders verici bir tarzı ortaya 
koymaktadır. Ö42' de “Para benim nasıl istersem harcarm. Bu seni ilgilendirmež" şeklinde sözlerin geçmesi de başkalarına karşı nazik olmayan bir konuşma tarzının çocuk tarafından duyumsanmasına aracılık edecek bir başka durumdur. Ö51'de “...ăğ̨n çok kirli, ... çok kötü kokuyorsun... sürekli kaşımp duruyorsun” gibi ifadelerle başkalarına karşı kibar/nazik olmamayı içeren ifadelerin yer aldığı bir anlatımın benimsenmiş olması da sosyal beceri öğretimi noktasında risk teşkil eden benzer bir bulgudur.

Çalışma grubundaki öyküler arasında “uyum” boyutu altında yer alan sosyal becerilerden sırasıyla söz dinleme, görevini yerine getirme, kurallara uyma ve izin isteme gibi becerilerin kısmen daha fazla olduğu görülmekle birlikte, grup ile birlikte hareket etme, plan yapma, çevreyi koruma, yeni durumlara uyum sağlama, verdiği sözü tutma gibi sosyal becerilerin de daha az olduğu görülmüştür. Bu boyut altındaki sosyal becerilerle ilgili durumları örneklendirmek gerekirse; Ö3'de yer alan

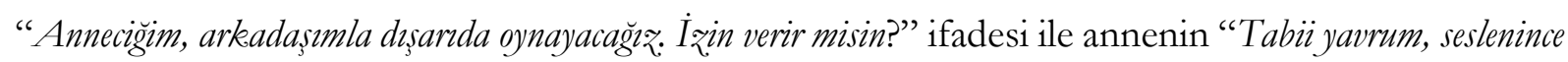
gel olur mu?” sözü karşısında “olur annecim” diyen ifadelere yer verilmiş olması gerektiğinde izin isteme ve ayrıca kurallara uyma becerisi için bir adımdır. Ö16'da ağaçtan kirazlarını yemek için izin isteyen karaktere yer verilmiş olması da çocuğun duyumsayarak izin isteme becerisini öğrenmesi noktasında katk1 sağlayıcıdır. Ö31'de gece ile gündüzü karıştıran filin geceleri bütün hayvanları rahatsız etmesi ve sonrasında kendisinin gündüz uyumaya çalışırken arkadaşlarının oyun oynaması ile onun rahatsız olması sonucunda, gece-gündüzü karıştırmaması ile gündüzleri oynaması ve geceleri uyuması kurallara uyulması gerektiğini öne çıkaran bir durumdur. Bununla birlikte, Ö57'de yer alan “Çöplerin yanında oynayan bebek filleri görünce çok hu₹ursuz olmuş. Eline bir süpürge alpp sabili temiəlemeye başlamış... Haydi yardim edin de birlikte temizleyelim sabili..." ifadeleri ve pis suyu denize dökmek isteyen kamyonun önüne dikilerek okyanusun yanına bile yaklaştırmamaları, çevreyi koruma ile sorumluluk alma (beraberinde başkalarının sorunlarına karşı duyarlı davranma ve yardım etme) gibi bir takım becerileri vurgulayan süreçlerdir. Bu çerçevede öykülerde yer alan ifadeler eşliğinde ayrı boyutlar altında yer alan farklı birçok sosyal becerinin gelişimine yönelik süreçlerin de işletilebildiği yönünde bulguya ulaşılmıştır.

Öykülerde daha azınlıkta bir şekilde rastlanan "atılganlık” boyutu altında yer alan sosyal becerilerin ise daha az çeşitteki sosyal becerilerden oluştuğu da çalışmada ortaya konan bir başka bulgudur. Bu kapsamda yer alan bağımsız olarak karar alma, liderlik rolünü üstlenme, kendine güvenme ve gerektiğinde kendini savunma gibi becerileri içeren sınırlı sayıda örneğe ulaşılmıştır. Bu örnekler değerlendirildiğinde; Ö12'de ceylanın sürünün başına geçmesine ilişkin senaryoların olması, liderlik rolünü üstlenmeye ilişkin bir örnektir. Ö50'de resim yapmak istemeyen karakterin öğretmenin 
rehberliğinde kuma çubukla resim yapabildiğini görmesinden sonra kâğıt üzerine resim yapabileceğini düşünmeye başlaması da kendine güveni öne çıkaran bir durumdur.

Çalışma grubundaki öykülerde ele alınan sosyal becerilerin nadiren de "kendini kontrol" boyutu altındaki becerilerden biri olduğu ve bunların öfkesini kontrol etme, korkuları ile baş etme ve işbirliği yapmaktan kaçınmama şeklinde öne çıkan sınırlı sayıdaki beceriler olduğu görülmüştür. Bu kapsamda Ö10'daki öyküde çocuklar için olası korku kaynağı olan canavar düşüncesi ile baş etmeye yönelik anlatımların yer alması oldukça önemli bir durumdur. Benzer bir şekilde, Ö33’de ördeğin duyduğu seslerden ve karanlıktan korkarak uyumaması şeklinde bir serüvene yer verilirken; annenin yavrularına oradakinin canavar değil, onlara iyi uykular dileyen ateş böcekleri ve baykuş olduğunu ve sonra otlarla dans eden rüzgârın sesi olduğunu açıkladığı görülmüştür. Ardından da çocuğun "Gece neden karanllk. ki bu kadar" sorusu üzerine "Gece bu kadar karanhk olmasaydl, yuldızlar böyle parlayamazdr. Karanlık gecede yalnı hissedersen kendini sana göz kirpan yuldıұlara sen de kırp gözlerini, kim bilir uyken arkadaşın olurlar belkel” diyerek korku verici durumla olumlu yönde baş etme duygusu desteklenmeye çalış1lmıştır. Ö46'da " $O$ zaman iş bölümü yapalım kim ne yapacak belli olsun” görüşü eşliğinde “Oturup konuștular. Tartşsıp anlaştılar. Ne güzel!’” şeklindeki ifadelerle sorunun çözümüne yönelik bir fikir bulmak amacıyla, iş bölümü yapmaktan kaçınmama (ayrıca uzlaşma) ile ilgili becerilerin kullanımına vurgu yapıldığı saptanmıştır.

\section{SONUÇLAR, TARTIŞMA VE ÖNERİLER}

Çalışma amacı doğrultusunda yapılan değerlendirmeler sonucunda, çalışma grubunda yer alan öykülerin bir kısmında sosyal becerilerin işlenme süreçlerinin daha sınırlı olduğu görülürken, tamamında sosyal becerilerin olumlu yönde desteklenmesine yönelik süreçlerin bir şekilde yer aldığ1 saptanmıştır. Bu sonuç, çalışmada ele alınan öykülerde sosyal becerilerin gelişimine yönelik birtakım unsurların ulaşılabilir olduğunun bir ifadesi niteliğindedir. Bu çerçevede, öykülerin içeriğine göre çocukların sosyal ve duygusal gelişim alanıyla ilgili beceri ve davranışlarının desteklenmesinde bir uyaran olduğu öne çıkmaktadır. İlgili alanyazınında sosyal öykülerle çocukların bağımsız davranma ve oyunun kurallarına uygun davranışlar sergileme (Barry ve Burlew, 2004), başkalarının duygularını anlama ve işbirliği içerisinde olma (Downs ve Smith, 2004), sorulan sulara cevap verme (Delano ve Snell, 2006; Ivey, Heflin ve Alberto, 2004), kendini kontrol etme (Koegel, Koegel, Hurley ve Frea, 1992) ve arkadaş edinme (Whitehead, 2007) gibi sosyal becerilerdeki yetersizliklerinin giderilebildiği yönünde sonuçların yer alması da bu durumların katkısını ortaya koymaktadır. Çalışma grubunda yer alan öykülerde sosyal becerileri olumlu yönde destekleyici şekilde geçen sosyal beceri sayılarının en az 1-2'den en fazla 9 ve üzerine kadar değişen sıklıklarda olduğu belirlenirken, öykülerde bu 
yönde işlenen ağırlıklı sosyal beceri sayısının 3-4 olduğu görülmüştür. Aksoy’un (2014) sosyal beceri içerikli hikâyelerle verilen eğitimin anasınıfına devam etmekte olan çocukların farklı yöndeki sosyal becerilerinin gelişiminde etkili olduğunu saptaması da bu kapsamdaki sonuçların önemini vurgular niteliktedir. Okul öncesi dönemden başlayarak farklı yaş gruplarına uzanan özel gereksinime sahip çocuklar üzerinde yürütülen çalışma sonuçları (Crozier ve Tincani, 2007; Kuoch ve Mirenda, 2003; Lorimer, Simpson, Myles ve Ganz, 2002; Özdemir, 2008; Rogers, 2000) da öykülerin sosyal beceri edinimini desteklemeye yönelik bir içeriğe sahip olması ile problem davranışların azalması üzerinde katkı sağlayıcı olduğuna dikkat çekmiştir. Henüz okuma bilmeyen/yapamayan okul öncesi dönem çocuklarının öykülerdeki sosyal becerileri anlamasında görsel sembollerden faydalanılmasının gerekli olması (Crozier ve Sileo, 2005) da öykülerin bu kapsamdaki unsurlarını önemli kılmaktadır.

Çalışmadaki öykülerde daha az oranda olmasına karşın, sosyal becerileri olumsuz yönde destekleyen ifadelerin yer aldığı ve sosyal becerileri olumsuz yönde işleyen öykülerin toplamda \% 13.33 oranında olduğu yönünde bir sonuca da ulaşılmıştır. Öykülerde olumsuz yönde desteklenen sosyal beceri sayılarının 1-2 ile 3-4 şeklinde değişiklik gösterdiği görülmekle birlikte, bu sayıların 1-2 sosyal beceri üzerinde yoğunluk gösterdiği bulunmuştur. Bahsi geçen bu kapsamdaki öykülerin nazik olmayan konuşmalar/davranışlar, şiddet içerikli öğeler ve aşağılayıc1/yargılayıcı yaklaşımlar ile sosyal becerilerin gelişimi üzerinde olumsuz yönde bir uyarana sahip olduğu belirlenmiştir. Öykülerde yer alan anlatımların bunu duyumsayan çocuğun davranış kalıpları üzerinde bir örnek teşkil edebileceği düşünüldüğünde, bu bağlamda yer alan her bir olumsuz uyaranın risk yaratan bir durum olduğu ortaya çıkmaktadır. Ulusal düzeyde yapılan çalışma sonuçlarında (Dağlığlu ve Çamlıbel Çakmak, 2009; Fırat, Güleç, ve Şahin, 2013, Öztürk ve Giren, 2016) da çocuk kitaplarında korku ve şiddet içerikli unsurlar başta olmak üzere birtakım olumsuz uyaranların yer aldığı görülmüştür. Okul öncesi dönem çocuklarına okunan öykülerin çocukların iletişim becerilerinden okuma becerilerine olumlu yönde bir etkiye sahip olmasının (Meyer, Stahl, Linn ve Wardrop, 1994) da ancak bu kapsamda yeterli olmasıyla mümkün olacağı bir gerçektir.

Çalışma kapsamındaki bir öyküde teşekkür etme, özür dileme gibi sosyal becerileri öğretmeye yönelik bir durum olarak çocuğa gerçek sihirli sözleri bilmemesinden dolayı cezalı olduğu belirtilerek, başkalarına karşı kibar olmayı öğrenmesi gerektiğinin açıklanması, durumun önemini hissettirmekten daha ziyade ders verici bir tarzı ortaya koymaktadır. Bir diğer öyküde çocuğun azarlayıc1 bir ifadeyle ("Para benim nasil istersem harcarm. Bu seni ilgilendirmez", şeklinde) nazik olmayan bir konuşma tarzını kullanarak olay kurgusuna dâhil olduğu görülürken, bu durumun çocuğun uygun olmayan bir davranışı duyumsamasına yol açan bir unsur olabileceği de söylenebilir. Böylesi 
anlatımlarla beceriyi öğretmeye çalışmak yerine anlatılarda çocuğun davranışının uygun olmadığını görebileceği süreçlere yer verilmesi daha uygun olacaktır. Sosyal beceri öğretiminde model olma ve rol oynama gibi birçok tekniğe başvurulabilirken, ceza gibi olumsuz süreçlerden de kaçınılması gerekmektedir. Çünkü cezanın çocuğun duygusal olarak örselenmesine yol açarak, özgüven sahibi olma gibi başka sosyal becerilerin zarar görmesine yol açması olasıdır. Neticede sosyal beceriler, bireyin sosyal davranışının ceza alma olasıllı̆ının azalması ve pekiştirme alma olasıllğının artması yoluyla ortaya çıkan davranışlar olmaktadır. Yine bir öyküde bağırma ifadesinin geçtiğine ve çeviri eser olan bir başka öyküde de öfkesini kontrol edememe, başkalarına karşı kibar/nazik olmama ve başkalarına karşı hoşgörülü olmama durumlarını içeren tepkilerin öne çıkarıldığına rastlanmıştır. Buradaki örneğe paralel bir şekilde, Dağlıoğlu ve Çamlıbel Çakmak (2009) okul öncesi dönem çocuklarına yönelik öykü kitaplarındaki metinlerde bağırma, saldırma ve canını acıtma şeklindeki şiddet öğelerine daha çok yer verildiğini saptamıştır. Fırat, Güleç ve Şahin (2013) de öykülerde bağırma, hakaret etme, tehdit etme, saldırma ve öldürme gibi şiddet içerikli kelimelere rastlandığını ortaya koymuştur. Benzer bir şekilde Öztürk ve Giren'in (2016) çalışmasında ise okul öncesi dönem çocuklarına yönelik öykü kitaplarında bağırma, canını acıtma ve hakaret etme şeklinde şiddet unsurlarının belirgin bir oranda yer aldığı belirlenmiştir. Çocuğun bu süreçleri duyumsamasının, olumsuz tutum ve davranışları model alması noktasında önemli bir risk teşkil ettiği söylenebilir. Bu nedenle, çeviri eserleri en başta olmak üzere çocuklara yönelik öykülerde yer alan anlatımların çocuklarla buluşturulmadan önce gözden geçirilmesi önemli bir husus olmaktadır.

Çalışma kapsamındaki birkaç öyküde ağırlıklı olarak kazandırılmaya çalışılan sosyal beceri üzerinde durulurken, birtakım başka sosyal becerilerin zarar görmesinin sağlanabileceği anlatımlara da yer verildiğine rastlanmıştır. Örnek olarak, “...ağg̨n çok kirli, ... çok kötü kokuyorsun ... sürekli kaşımp duruyorsun” gibi ifadelerle çocuğa temiz olması gerektiği aktarılmaya çalış1lırken, başkaları ile iletişim kurarken uygun bir dil kullanması gerektiği iletisi de göz ardı edilmiştir. Böylesi bir anlatımın yerine olay kurgusu içerisinde temizliğin önemli olduğunun sezinletilmesinin daha uygun olabileceği düşünülmektedir. Nitekim okul öncesi dönem çocuklarına yönelik anlatımlarda çocuğun yaşamında önemli olan öğelerin çocuk gerçekliğiyle ortaya konması esastır. Başka bir öyküde ise emir cümleleri ("Hayvanlara daima sevgiyle davranmahıın... Seni doktora götürdüklerinde orada sakin olmalısı"...) eşliğinde çocuğun nasıl davranması gerektiğinden bahsedilmesi ve bu koşullar sağlandığında çocuğun yanında olunacağının belirtilmesi, ders verme niteliğindeki anlatımlarla öğretim yapan süreçler olmakta ve çocuğun koşullu kabulle karşılaşmasına yol açmaktadır. Öykülerde yer alan bu şekildeki yargılar yinelendikçe, özelliğini yitirebilmekte ve çocukların neden-sonuç ilişkisiyle düşünmelerine engel olabilmektedir. Oysa çocuk kitaplarında yazarın çocuğa göre kurguladığı, çocuk için uygun 
yaşam durumlan, çocukların belleklerinde yanıtlanması gereken soruları oluşturmalıdır. "Çevremde yaşayan diğer canlilara karşı niçin duyarl davranmalyym?" ya da "Cevremde yaşayan diğer canhlara duyarl

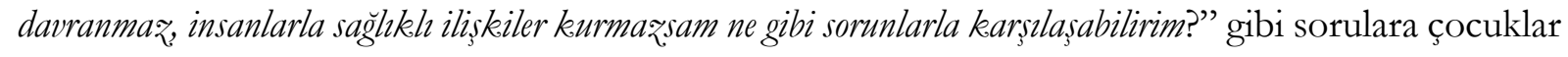
yanıt aramaya kendileri koyulmalıdır. Dolayısıyla, çocuk kitaplarının öğretme sorumluluğu çocukların belleklerinde nitelikli sorular oluşturmaya yönelik olmalı ve bu doğrultuda çocuğu özgürlüğüne ve kendini gerçekleştirmeye yönlendirmelidir. Çocuğu bir yetişkinin oluşturduğu doğrulara bağımlı kılmak isteyen güdümlü yayınlar, çocuklarda kitap ve edebiyat adına yanlış kanıların oluşmasına ve zamanla çocuğun okuma isteğinin körelmesine yol açabilmektedir. Bu durumlar karşısında çocuk ile kitap arasında engellerin oluşması da olası bir durumdur (Sever, 2003). Çocuk yazınlarının öğretici olma özelliği, çocuğun düşüncesine el konarak birtakım değerleri çocuğa zorla benimsetme süreci olarak ele alınmamalıdır. Bunun yerine çocuğa öyküde anlatılanları duyumsatma ve çocuğun anlatılanlarla özdeşleşmesini sağlama ile düş gücünü harekete geçirme asıl amaç olmalıdır.

Çalışma grubundaki öykülerde yer alan olay kurgularının aktarımında büyük oranda hayvan karakterlerine yer verilmiş olduğunun görülmesi de çocukların sevdiği canlılardan yola çıkarak özdeşleşmesini sağlama ve aynı zamanda hayvanların ön plana çıkan özelliklerinden yola çıkarak insan davranışlarından benzetmeler yapma noktasında katkı sağlayıcıdır. Örneğin; keçiler inatçı davranışları ve kuzular masum tavırları ile öyküdeki anlatımlara dâhil olabilecek karakterler olurken, uygun sosyal becerilerin sezdirilmesine de katk1 sağlayan durumlar olabilmektedir (Dilidüzgün, 2004). Bu tür doğrudan ders verme havasından uzak yaklaşımlarla, çocuğa uygun sosyal becerilerin sezdirilerek kazandırılmış olması da mümkün olabilecektir. Benzer bir şekilde, Kucirkova (2019) öyküler aracıllğıyla çocuklara empati becerisinin kazandırılmasında, öykünün çocuğun öyküyle bütünleşmesini sağlayacak bir şekilde kurgulanmış olmasına ve kendisine ilginç gelebilecek bir şekilde kendinden farklı karakterlerle çocuğu özdeşleştirmesine ihtiyaç olduğunu vurgulamıştır.

$\mathrm{Bu}$ anlamda bazı eserlerin içerisinde sosyal becerilere değiniliyor olmasına karşın, okul öncesi dönem çocukları için daha etkileyici bir içerikle sunulmasına ihtiyaç olduğu ileri sürülebilir. Buradaki öyküde birçok sosyal beceriyi destekleyecek şekilde serüvenlere yer verilirken, "aptallık etme" şeklinde bir ifadeye de yer verilmiş olması hakaret etme şeklindeki şiddet içerikli bir sözcüğün duyumsanmasına yol açacak bir durumdur. Bu ifadenin geçtiği öykü ile bir başka öykü içerisinde canavarlara yönelik korkularla baş etmeye yönelik süreçlere yer verilmiştir. Okul öncesi dönem çocuğunun dünyasında canavar algısının çözümlenmesi gereken bir durum olarak ele alınması katkı sağlayıcı bir durum olacaktır. Çocuğa korku verici bir durumla başetme gücü kazandırılırken, 
kendisini aşağılanmış hissetmemesi de ayrıca önemli bir husustur. Dağlığlu ve Çamlıbel Çakmak (2009) okul öncesi dönem çocuklarına yönelik öykü kitaplarında korku öğesi olacak şekilde, aşırı sihir öğeleri ve esrarengiz olaylar ile ilgili sözcüklerin yer aldığını vurgulamıştır. Buna ilisskin örneklere, okul öncesi dönem çocuklarına yönelik öykü kitapları üzerinde yürütülen Fırat, Güleç ve Şahin (2013) ile Öztürk ve Giren’in (2016) çalışma sonuçlarında da ulaşılmıştır. Korku ve şiddet gibi durumların sosyal becerilerle bağdaşmayan unsurlar olduğu düşünüldüğünde, öykülerin sosyal beceriler üzerinde katkı sağlayıcı olması için bu çerçevedeki özelliklerinin nitelikli hale getirilmesine son derece ihtiyaç duyulmaktadır. Çocuklara yönelik öykü kitaplarının çocuğa kendisini sınama ve çevresini tanıma firsatı verecek olması sebebiyle, öykülerde yer alan her bir unsurun öykünün içerisine özenle dâhil edilmiş olması gerekmektedir.

Çalışmadan elde edilen sonuçlar arasında öykülerde ele alınan sosyal becerilerin ağırlıklı olarak “iletişim" boyutundan ve akabinde "prososyal davranışlar" boyutundan sosyal beceriler olduğu ve bu durumları "uyum” boyutundan sosyal becerilerin takip ettiği ortaya konmuştur. Bu sonuç, araştırmanın ikinci alt amacı doğrultusunda tespit edilen sonuçta da görüldüğü üzere; öykülerde duygu ve düşüncelerini ifade etme, soru sorma, sorulara cevap verme gibi “iletissim” boyutundan ve teşekkür etme, yardım etme, özür dileme, başkalarına karşı nazik davranma gibi "prososyal davranışlar" boyutundan sosyal becerilerin çok daha doğal bir şekilde süreç içerisinde aktarıllyor olmasından kaynaklanmış olabilir. Bu durumu destekler bir şekilde, Aksoy’un (2014) çalışmasında hikâye temelli sosyal beceri eğitiminin "iletişim" ve "prososyal davranışlar" boyutundaki sosyal beceriler üzerinde olumlu yönde öncelikli bir etkiye sahip olduğu saptanmıştır. Esteban Sidera, Serrano, Amado, ve Rostan'un (2010) resimli kitap okuma programının okul öncesi dönem çocuklarının başkalarının duygu, düşünce ve davranışlarını anlama, değişikliklere uyum sağlama gibi becerilerinin gelişiminde etkili olduğunu belirlemesi de öykülerin "uyum” boyutunda yer alan sosyal becerilerin üzerindeki payını vurgular niteliktedir. Tosunoğlu ve Kayadibi’nin (2006) çalışmasında Milli Eğitim ile Kültür Bakanlığı’nın yayınladığı çocuk kitaplarında daha çok doğruluk, iyilik ve çalışkanlık gibi boyutlar altındaki davranışların ele alındığının tespit edilmesi, bu kapsamdaki sosyal beceri unsurları açısından önemlidir. Nitekim çocuk haklarının ihlâl edilmediği çocuk edebiyatı ile ilgili eserler aracıllğıyla, çocuklara sorumluluk, hoşgörü ve adalet gibi birçok kavramın kazandırılması söz konusudur (Mendoza ve Debbie, 2001). Güzelyurt ve Özkan'in (2019) okul öncesi dönem çocuklarına yönelik resimli öykü kitaplarının çocukların çevre sorunlarına karşı duyarlı olmalarını ve çevreci birey olma anlayışıyla yaklaşmalarını sağlama bakımından yeterli düzeyde olmadığını saptaması da bu kapsamdaki bir sorunu ortaya koymaktadır. 
Bu kapsamda elde edilen bir başka sonuç olarak; çalışmada incelenen öykülerde çok daha azınlıkta bir şekilde ele alınan sosyal becerilerin "atılganlık" boyutundan ve nadiren de "kendini kontrol" boyutundan sosyal becerilerden oluştuğu tespit edilmiştir. Ele alınan "atılganlık" boyutundan sosyal becerilerin bağımsız olarak karar alma, liderlik rolünü üstlenme, kendine güvenme, cesur olma ve gerektiğinde kendini savunma gibi daha az sayıdaki sosyal beceriler olması da öykülerin bu yönde içeriğe sahip olma eğilimlerinin daha sınırlı olduğunun bir göstergesi olabilir. Bu becerilerin çocuk üzerindeki etkileri göz önüne alındığında; çocukların girişimci, öz yeterlilik sahibi ve cesaretli bireyler olabilmeleri için bu becerileri duyumsamasına ihtiyaç olduğu düşünülmektedir. Çalışmadan elde edilen bu yöndeki sonuçlara paralel bir şekilde, Dirican ve Dağlığlu (2014) da okul öncesi dönem çocuklarına yönelik öykü kitaplarında cesaret, liderlik ve barış gibi değerlerin en az yer alan değerler olduğunu saptamıştır. Akyol'un (2012) okul öncesi dönem çocukları için yazılmış resimli çocuk kitaplarında alçakgönüllülük, dürüstlük, özgürlük, saygı ve uyum gibi değerlerin düşük oranda yer aldığını tespit etmesi de bu kapsamda düşündürücüdür. Başka bir çalışmada (Büyükalan ve Harmankaya, 2019) ödüllü resimli çocuk kitaplarında çocuğun korunma ve katılım hakkı ile ilgili resimlerin ve metinlerin daha az yer aldığının saptanması da çocuğun davranışlarına yönelik olarak kitaplara yansıyan eğilimlerin ne yönde ağırlık gösterdiğinin bir göstergesi olarak değerlendirilebilir.

Çalışma grubundaki öykülerde yer alan sosyal beceri ifadeleri genel olarak ele alındığında; öykülerde hatasını kabul etme, teşekkür etme, yardım etme, duygu ve düşüncelerini ifade etme, özür dileme, birlikte oyun oynama, soruna yönelik bir çözüm bulma, başkalarına karşı kibar/nazik olma, karşılaşma ifadesini kullanma ve anlamadığı bir durum olduğunda soru sorma gibi becerilerin öne çıktığ1 sonucuna ulaşılmıştır. Burada bahsi geçen sosyal becerilerin öykülerde ağırlıklı olarak yer almasının nedenlerinden biri, okul öncesi dönem çocuklarına kazandırılması gereken öncelikli beceriler arasında görülmesi ile ilişkili olabilir. Nitekim öykü içerisinde birtakım karakterlerle olay kurgusu yer almakta ve verilmek istenen iletiye göre karakterler ile olay kurgusu arasında süreç devindirilmektedir. Bu çerçevede çocuklara yönelik eserlerin duyarlılık kazandırma amacı içerisinde olması gerekmektedir. Çünkü çocuk edebiyatı eserlerinde anlamadan, sorgulamadan karar veren insanlar yerine; düşünerek ve duyumsayarak karar verebilecek duyarlı insanların yetiştirilmesi söz konusudur (Sever, 2003). Diğer bir açıdan ise öykülerdeki olay kurgularının dinleyici çocuk ile paylaşılması sürecinin iletişim kurma, soru sorma, ifade etme, yardım ve teşekkür etme gibi iletileri doğal olarak beraberinde getirmesi de bu yöndeki kazanımların daha çok olmasını sağlamış olabilir. Benzer bir şekilde, Dirican ve Dağlığlu (2014) üç-altı yaş çocuklarına yönelik öykü kitaplarında paylaşmak, arkadaşlık ve nezaket gibi değerlerin en çok rastlanan değerler olduğunu saptamıştır. Bir başka çalışma sonucuna göre (Turan ve Ulutaş, 2016) de resimli öykü kitaplarında ele alınan konular 
arasında sosyal ilişkiler, özgüven, yardımlaşma, aile, duygular ve arkadaşlık-dostluk ön sıralarda yer almaktadır. Bu sonuçlara paralel bir şekilde, Angın ve Soydan (2017) da okul öncesi öğretmenlerinin tercih ettikleri hikâye kitaplarında sevgi, duygular, arkadaşlık ilişkileri ve yardımlaşma ile ilgili kavram ve becerilerin ağırlıklı olarak yer aldığını belirlemiştir. Dilidüzgün’e (2004) göre de dört yaşından itibaren çocuğun yaşamını yakından ilgilendiren bazı kavramların çocuk kitabında yer alarak bunların çocuğa öğretilmesi zorunluluk arz etmektedir. Çalışkan olma, başkalarını rahatsız etmeme, paylaşma, hoşgörülü olma gibi kavramların anlatılarda yer alması gerekli görülmektedir. Öykülerde ilk aşamadaki sosyal becerilere göre çok daha azınlıkta bir şekilde olmak üzere; kurallara uyma, izin isteme, paylaşma, sorumluluk alma, iltifat etme, soruna yönelik alternatif fikir üretme, başkalarına 'nasılsınız' diye sorma, arkadaş edinme, bağımsız olarak karar alma, ihtiyaç durumunda başkalarının fikrini alma, gerektiğinde 'lütfen’ deme, korkuları ile baş etme, uzlaşma, dikkatli dinleme, liderlik rolünü üstlenme, sayg1lı olma, yaptığı işe özen gösterme, başkalarına karşı güler yüzlü olma ve yeni şeyler denemeye istekli olma gibi sosyal becerileri öne çıkaran anlatımların da yer aldığ1 saptanmıştır. Yapılan bir çalışma sonucu (Cengiz ve Duran, 2017) da okul öncesi dönem çocuklarına ait kitaplarda alçak gönüllülük, hoşgörü, misafirperverlik ve sayg1 gibi değerlerin oldukça az vurgulandığını ortaya koymuştur. Bu becerilerin öykülerde daha az işlenmesi bu becerilerin eksikliğinin doğrudan bir tehdit unsuru olarak algılanmamasından veya yazarlar tarafından elzem görülüp görülmeme durumundaki farklılıktan kaynaklanmış olabilir. Sosyal becerilerin birbirini etkileyen ve birbirinden etkilenen çok boyutlu öğrenilmiş davranışlar olduğu görüşünden hareketle, herhangi bir alandaki eksikliğin başka bir alandaki gelişim ve öğrenme için sorun teşkil edebilecek bir durum olduğu söylenebilir. Örneğin; yeni şeyler denemeye istekli olmayan bir çocuğun grup etkinliklerine aktif katılım göstermesi beklenemezken, başkalarına karşı nazik davranmayan birinin arkadaşları tarafından kabul edilen biri olması da çok muhtemel bir durum olmamaktadır. Bunların yanında, çalışmada kapsamındaki farklı öykülerde ele alınmış sosyal beceriler arasında birer defa olmak üzere başkalarını uygun olan bir duruma ikna etme, merak ettiği bir durumu öğrenmek için çabalama, gerektiğinde başkalarını rahatlatma, cesur olma, gerektiğinde 'hayır' deme, güçlü ve zayıf yönlerinin farkında olma, gerekli durumlarda "geçmiş olsun” deme, oyuna davet etme ve grup ile birlikte hareket etme gibi becerilerin de yer aldığı sonucuna ulaşılmıştır. Bu sonuç, öykülerin bu kapsamdaki sosyal becerileri işleme oranlarının çok düşük olduğunun bir göstergesidir. Bu kapsamda yer alan sosyal becerilerin de çocuğun kendini ve çevresini tanımasına katkı sağlayan ve kendi hakları açısından bir sorun yaratmadan başkası açısından uygun olacak davranışları sergilemesini teşvik eden beceriler olduğu söylenebilir. Buna göre, öykülerin çocukların çevreyle sağlıklı ilişkiler kurmasına ve kendisiyle barışık kişiler olarak var olmasına katkı sağlayacak türden bir içeriğe sahip olması da son derece önemlidir. Dirican ve Dağlıŏ̆lu (2014) üç-altı yaş 
çocuklarına yönelik öykü kitaplarında cesaret, liderlik ve barış gibi değerlerin en az oranda yer aldığını saptamıştır. Bildirici ve Bulut Pedük'ün (2017) çalışmasında da anaokullarının sınıf kitaplıklarında bulunan öykü kitaplarında mücadele etme, selamlama, duyarlılık, çalışkanlık, kendini kabul etme, özgüven, sorumluluk, hoşgörü, empati, farkında olma, girişimcilik ve liderlik gibi değerlerin işlenme sıklıklarının değişiklik gösterdiği belirlenmiştir. Dolayısıyla, okul öncesi dönem çocuklarına seslenen öykülerin içeriklerinin sosyal beceri gelişimini çok yönlü destekleyecek bir şekilde yapılandırılmış olmasının bir gereklilik olduğu göz ardı edilmemesi gereken bir durumdur. Çalışmada elde edilen sonuçlar ışığında; alanda çalışan kişilere, araştırmacılara ve öykü yazarlarına aşağıdaki öneriler ileri sürülebilir.

- Okul öncesi dönem çocuklarına yönelik öykülerin sahaya sunulmadan önce sosyal beceriler açısından içeriklerinin de bir denetim mekanizması eşliğinde gözden geçirilmesi ve sahip olduğu sosyal beceri unsurları bağlamında uygun olan öykülerin çocuklar için ulaşılabilir olması önerilmektedir.

- Okul öncesi dönem çocukları için halihazırda yer alan öykülerde mevcut olan sosyal beceri unsurlarının öykü seçiminde dikkate alınması önerilmektedir. Okul öncesi eğitim alanında bu kapsamda yapılmış çalışma sonuçlarından öğretmenlerin ve ailelerin bilgi sahibi olması noktasında yaygın bir şekilde ulaşılabilir olan kitle iletişim araçlarından faydalanılabilir.

- Öykü yazarlarının kaleme alacakları öykülerde çocukların sosyal becerilerini olumlu yönde destekleyecek bir anlatımı benimsemeleri ve bu kapsamda sosyal beceriler açısından çok yönlü gelişimi sağlamaya yönelik bir içerikle öykülerdeki serileri ele almaları önerilmektedir.

- Okul öncesi dönem çocuklarına yönelik öykülerde "iletişim” ve "prososyal davranışlar" gibi boyutlar altında yer alan sosyal becerilerin gelissimine yönelik unsurların devamlıllğının sağlanması yanında, daha sınırlı bir şekilde ele alınan "atılganlık" ve "kendini kontrol" gibi boyutlar altında yer alan sosyal becerilerin gelişimi ile ilgili unsurların da mevcut olmasına özen gösterilmelidir. Bu kapsamda, öykü yazarlarının öykü içeriklerinin oluşturulmasında bağımsız davranma, kendine güvenme, cesur olma, liderlik gösterme, hakkını savunma, korku/kayg1 verici durumlarla baş etme ve öfkesini kontrol etme gibi sosyal becerilerin gelişimini sağlamaya yönelik bir anlayış içerisinde olmaları önerilmektedir.

- İleride yürütülecek olan çalışmalarda, farklı yayınevlerine ait öykü setleri bütüncül bir şekilde ele alınabilir ve daha geniş örneklem üzerinde yayınevinde yer alan öykülerin konu, içerik, tema gibi farklı unsurlar bağlamında karşılaştırmalı olarak değerlendirmesi yapılabilir. Farklı boyutlar altındaki sosyal becerileri ele alan öykü kitaplarının çocukların çeşitli kavram ve beceri düzeyleri üzerindeki etkisi deneysel çalışmalarla incelenebilir. Bu süreçler üzerinde öğretmen farkındalığı ve ebeveyn davranışları gibi durumların etkisi de ayrıca araştıılabilir. 


\section{KAYNAKÇA}

Akınc1, S.. (2015). Resimli çocuk kitaplarnda yer alan miz̧abi unsurlarm incelenmesi. Yayımlanmamış Yüksek Lisans Tezi, Hacettepe Üniversitesi Eğitim Bilimleri Enstitüsü, Ankara.

Aksoy, P. (2014). Hikâye anlatma temelli ve oyun temelli sosyal beceri eğitiminin anasinfina devam eden cocuklarm sosyal becerilerine etkisinin incelenmesi. Yayımlanmamıs Doktora Tezi, Ankara Üniversitesi Fen Bilimleri Enstitüsü, Ankara.

Akyol, T. (2012). Resimli çocuk kitaplarnnda yer alan değerlerin incelenmesi. Yayımlanmamış Yüksek Lisans Tezi, Hacettepe Üniversitesi Sosyal Bilimler Enstitüsü, Ankara.

Alptekin, Z. D. (2018). 3-6 yaş grubu çocuklara yönelik yayımlanan resimli hikâye kitaplarının temel fen kavramları açısından incelenmesi. Uluslararası Cocuk Edebiyatı ve Eğitim Araștırmalar Dergisi, 2(1), 76-86.

Angın, E. ve Soydan, S. (2017). Okul öncesi öğretmenlerinin tercih ettikleri hikaye kitaplarında yer verilen kavram ve becerilerin analizi. Eğitim ve Ögretim Araștırmalar Dergisi, 6(3), 99-112.

Barry, L. M. and Burlew, S. B. (2004). Using social stories to teach choice and play skills to children with autism. Focus on Autism and Other Developmental Disabilities, 19(1), 45-51.

Baş, N. (2011). Hikâye temelli eğitim programmm 60-72 ayllk çocuklarn sorumluluk ve işbirliği becerilerinin gelişimine etkisinin incelenmesi. Yayımlanmamış Yüksek Lisans Tezi, Marmara Üniversitesi Eğitim Bilimleri Enstitüsü, İstanbul.

Bencik Kangal, S., Karaaslan, A., ve Arslan, S. (2018). Okul öncesi dönem resimli çocuk kitaplarında yer alan baba figürünün incelenmesi. Uluslararası Cocuk Edebiyatı ve Eğitim Arastırmalan Dergisi, 2(2), 18-31.

Bildirici, Z. ve Bulut Pedük, Ş. (2017). Değer eğitimi konusunda anaokullarının sınıf kitaplıklarında bulunan hikaye kitaplarının incelenmesi. Social Sciences Studies Journal, 3(12), 2225-2236.

Büyükalan, F. S. ve Harmankaya, T. (2019). Ödüllü resimli çocuk kitaplarında çocuk haklarının incelenmesi. Millì Ë̆itim, 48(1), 769-791.

Büyüköztürk, Ş., Kilıç Çakmak, E., Akgün, Ö., Karadeniz, Ş. ve Demirel, F. (2018). Bilimsel araștırma yöntemleri (25. bask1). Ankara: Pegem Akademi.

Çeçen, M. A. ve Aydemir, F. (2011). Okul öncesi hikâye kitaplarının okunabilirlik açısından incelenmesi. Mustafa Kemal Üniversitesi Sosyal Bilimler Enstitüsü Dergisi, 8(16), 185-194.

Cengiz, Ş. ve Duran, E. (2017). Okul öncesi dönemine ait hikâye ve masallardaki değerlerin incelenmesi. Ë̆itim ve Bilim, 191(42), 205-233.

Crozier, S. and Tincani, M. (2007). Effects of social stories on prosocial behavior of preschool children with autism spectrum disorders. Journal Autism Development Disorder, 37(3), 18031814. 
Dağlıoğlu, H. E. ve Çamlıbel Çakmak, Ö. (2009). Okul öncesi çocuklarına yönelik yayınlanan hikâye kitaplarının şiddet ve korku öğeleri açısından incelenmesi. Türk Kütüphaneciliği, 23(3), 510534.

Delano, M. and Snell, M. E. (2006). The effects of social stories on the social engagement of children with autism. Journal of Positive Behavior Interventions, 8(1), 29-42.

Dilek, A. (2017). Resimli hikaye kitaplarında yer alan oyuncakların incelenmesi. Erken Çocukluk Calısmalar Dergisi, 1(1), 81-93.

Dilidüzgün, S. (2004). Okulöncesi çocuk anlatıları. Z. Güneş (Ed.), Çocnk edebiyatı içinde (s.57-76). Eskişehir: Anadolu Üniversitesi Yayını No: 1420.

Dirican, R. ve Dağlıŏ̆lu, E. (2014). 3-6 yaş grubu çocuklarına yönelik yayımlanan resimli hikaye kitaplarının bazı temel değerler açısından incelenmesi. Cumburiyet International Journal of Education-CIJE, 3(2), 44-69.

Downs, A. and Smith, T. (2004). Emotional understanding, cooperation, and social behavior in high-functioning children with autism. Journal of Autism and Developmental Disorders, 34(6), 625-235.

Elliott, S. N., Gresham, F. M., Frank, J. L., and Beddow, P. A. (2008). Intervention validity of social behavior rating scales: Features of assessments that link results to treatment plans. Assessment for Effective Intervention, 34(1), 15-24.

Esteban, M., Sidera, F., Serrano, J., Amado, A., and Rostan, C. 2010. Improving social understanding of preschool children: Evaluation of a training program. Electronic Journal of Research Educational Psychology, 8(2), 841-860.

Fırat, H., Güleç, H., ve Şahin, Ç. (2013). Okul öncesi dönem çocuklarına yönelik hazırlanan masal ve öykü kitaplarının korku ve şiddet öğeleri açısından incelenmesi. The Journal of Academic Social Science Studies-International Journal of Social Science, 6(5), 217-241.

Fraenkel, J. R., Wallen, N. E. and Hyun, H. H. (2012). How to design and evaluate research in education ( $8^{\text {th }}$ edition). New York: McGraw-Hill Publications.

Gresham, F. M. and Elliott, S. N. (1990). Social skills rating system. Circle Pines, MN: American Guidance Service.

Güzelyurt, T. ve Özkan, Ö. (2019). Okul öncesi dönemde çevre eğitimi: Çocuk kitaplarına yönelik bir inceleme. İlkögretim Online, 18(1), 20-30.

Ivey, M. L., Heflin, L. J., and Alberto, P. (2004). The use of social stories to promote independent behaviors in novel events for children with PDD-NOS. Focus on Autism and Other Developmental Disabilities, 19(3), 164-176.

Justice, L. M., and Kaderavek, J. (2002). Using shared storybook reading to promote emergent literacy. Teaching Exceptional Children, 34(4), 8-13. 
Kaya Bağdaş, Ç. ve Demir, E. (2016). Okul öncesi öğretmenlerinin hikâye ve hikâye kitapları hakkındaki görüşlerinin incelenmesi (Erzincan örneklemi). Eržincan Üniversitesi Sosyal Bilimler Enstitüsü Dergisi (ERZSOSDE) ÖS-III, 219-230.

Koegel, L. K., Koegel, R. L., Hurley, C., and Frea, W. D. (1992). Improving social skills and disruptive behavior in children with autism through self-management. Journal of Applied Behavior Analysis, 25(2), 341-353.

Korkmaz, A., Koyuncu Şahin, M., ve Gönen, M. S. (2018). Türkçe ve Türkçe’ye çevrilmiş okul öncesi dönem resimli öykü kitaplarında yaşlılık kavramının incelenmesi. Uluslararası Eğitim Bilimleri Dergisi, 5(15), 125-140.

Körükçü, Ö., Acun Kapıkıran, N., ve Aral, N. (2016). Resimli çocuk kitaplarında Schwartz'ın modeline göre değerlerin incelenmesi. Mehmet Akif Ersoy Üniversitesi Ë̆gitim Fakültesi Dergisi, 1(38), 133-151.

Kucirkova, N. (2019). How could children's storybooks promote empathy? A conceptual framework based on developmental psychology and literary theory. Frontiers in Psychology, 10(121), 1-15.

Kuoch, H. and Mirenda, P. (2003). Social story interventions for young children with autism spectrum disorders. Focus on Autism and Other Developmental Disabilities, 18(4), 219-227.

Lorimer, P. L., Simpson, R. L., Myles, B. S. and Ganz, J. B. (2002). The use of social stories as a preventative behavioral intervention in a home setting with a child with autism. Journal of Positive Behavior Interventions, 4(1), 53-60.

Mendoza, J. and Reese, D. (2001). Examining multicultural picture books for the early childhood classroom: Possibilities and pitfalls. Early Childhood Research \& Practice, 3(2), 1-38.

Meyer, L. A., Wardrop, J. L., Stahl, S. A., and Robert L. L. (1994). Effects of reading storybooks aloud to children. The Journal of Educational Research, 88(2), 69-85.

Michelson, L., Sugai, D. P., Wood, R. P., and Kazdin, A. E. (1983). Social skills assessment and training with children: An empirically based handbook. New York: Plenum Press.

Miles, M. B. and Huberman, A. M. (1994). An expanded sourcebook: Qualitative data analysis. Thousand Oaks, CA: Sage Publications.

Oruç, C. (2010). Okul öncesi dönem çocuğunda ahlaki değerler eğitimi. Eğitim ve İnsani Bilimler Dergisi, 1(2), 37-60.

Özdemir, S. (2008). The effectiveness of social stories on decreasing disruptive behaviors of children with autism: Three case studies. Journal of Autism and Developmental Disorders, 38(9) 1689- 1696.

Öztürk, M. ve Giren, S. (2016). Okul öncesi dönemdeki çocuklar için hazırlanan hikâye kitaplarındaki korku ve şiddet öğelerinin incelenmesi. Uluslararası Türkşe Edebiyat Kültür Eğitim Dergisi, 5(4), 2095-2108. 
Rogers, S. J. (2000). Interventions that facilitate socialization in children with autism. Journal of Autism and Developmental Disorders, 30(5), 399-409.

Sever, S. (2003). Cocuk ve edebiyat (1. baskı). Ankara: Kök Yayıncılık.

Sonnenschein, S. and Munsterman, K. (2002). The influence of home - based reading interactions on 5-year-olds reading motivations and early literacy development. Early Childhood Research Quarterly, 17(3), 318-337.

Stanley, M. (2009). Çocuk ve beceri. İstanbul: Ekinoks Yayıncilık.

Tosunoğlu, M. ve Kayadibi, N. (2006). Türkiye'de 2000-2005 yıllarında devlet tarafindan yayımlanmış çocuk kitaplarının biçim ve içerik analizi. II. Ulusal Coouk ve Gençlik Edebiyatı Sempozyumu (Gelismeler, sorunlar ve çözüm önerileri), (Yay. Haz. S. Sever), (ss. 339-347). Ankara: Ankara Üniversitesi Eğitim Bilimleri Fakültesi Yayını.

Turan, F. ve Ulutaş, İ. (2016). Okul öncesi eğitim kurumlarındaki resimli öykü kitaplarının özellikleri ile öğretmenlerin bu kitapları kullanma durumlarının incelenmesi. Hacettepe Üniversitesi Eğitim Bilimleri Enstitüsü Eğitim Araștırmalar Dergisi, 2(1), 21-45.

Turan, F., Gönen, M., ve Aydos, E. H. (2017). Okul öncesi öğretmen adaylarının resimli öykü kitaplarını seçme konusunda yeterlik düzeyleri ve kendi yeterliklerine ilişkin algılarının incelenmesi. Abant İzet Baysal Üniversitesi Ë̈itim Fakültesi Dergisi, 17(1), 400-422.

Whitehead, J. (2007). Telling it like it is: Developing social stories for children in mainstream primary school. Postoral Care in Education, 25(4), 35-41.

Yekeler, A. D. ve Cengiz, Ö. (2018). Okul öncesi dönem çocuklarının sözsüz kitap anlatımlarında hikâye elementlerinin incelenmesi. Turkish Studies- Educational Sciences, 13(19), 1935-1952.

Yıldırım, A. ve Şimşek H. (2008). Sosyal bilimlerde nitel araştırma yöntemler (6. baskı). Ankara: Seçkin Yayıncilik.

Yıldız, C., Yazıcı, D. N., ve Durmuşoğlu, M. C. (2016). 2010-2015 yılları arasında yayımlanmış resimli çocuk kitaplarının resimleme özelliklerinin incelenmesi. Uluslararası Erken Çocukluk Eğitimi Çalşsmalar Dergisi, 1(1), 43-55.

Yurtseven, L. ve Kurt, G. (2013). Okul öncesi eğitimin ve annelerin hikâye kitabı okumasının çocukların sosyal beceri gelişimi ile ilişkisi. Cumburiyet Üniversitesi Edebiyat Fakültesi Sosyal Bilimler Enstitüsü Dergisi, 37(2), 99-119. 